\title{
Review on methods to deposit catalysts on structured surfaces
}

\author{
Valérie Meille * \\ Laboratoire de Génie des Procédés Catalytiques, CNRS-CPE, 43 bd du 11 \\ novembre 1918, BP 2077, 69616 Villeurbanne cedex, FRANCE
}

\begin{abstract}
The methods used to deposit a catalyst on structured surfaces are reviewed. Physical methods such as PVD and chemical methods (sol-gel, CVD, direct synthesis...) are described. The coating of catalysts based on oxide, zeolite or carbon support is detailed on various surfaces such as silicon or steel microstructured reactors, cordierite monoliths or foams, fibres, tubes...
\end{abstract}

Key words: Washcoating, coating, alumina deposition, carbon deposition, catalytic film, CVD, PVD, suspension, sol-gel, zeolite, structured reactor, wall-reactor, microreactor

\section{Introduction}

Structured catalysts and reactors are gaining more importance each year [1]. The use of microreactors and heat-exchanger reactors for fuel processing [2,3], but also for gas-liquid-solid reactions $[4,5]$ (screening and kinetics investigations) often requires a shaping of the catalyst. Micro-packed-beds of powder catalysts can sometimes be used [6], but in general, a very thin layer of catalyst that sticks to the reactor wall is preferred, because of mass and/or heat transfer improvement. Many methods can be used to deposit a catalyst layer on a surface, depending on the properties of the surface and the catalyst that has to be deposited. Concerning the deposition on monoliths, some reviews already exist $[7,8,1]$. Descriptions of some coating methods on microreactors can also be found [9]. We have decided not to be restrictive and to gather all published

* Corresponding author.

Email address: vme@lgpc.cpe.fr (Valérie Meille). 
catalyst coating methods than can be applied to some supports, either microstructured or not (e.g. foams, fibres, reactor walls, tubes...). The patented literature is not cited here but can be found in the above cited reviews. The two first methods detailed (anodic oxidation and thermal treatment) are often used as pretreatments. Sol-gel can also, in certain cases, be used to deposit a primer on the support to coat. On the opposite, impregnation is often used (as a post-treatment) to deposit a catalytic active phase on the washcoat and do not differ from powder impregnation. One example of combination of methods is given by Zhao et al. [10], who have prepared their coating in 3 steps: i) FeCrAl thermal oxidation, ii) boehmite primer deposition, iii) dip-coating in an alumina suspension. This allowed to increase the adherence of the alumina layer on the metallic support. All these methods have been described independently in the following paragraphs. This review is not restricted to oxide support deposition but also includes zeolite and carbon support coatings.

\section{Catalysts based on oxide supports deposited on various struc- tures}

This section presents the different methods used to obtain a metal-on-oxide catalyst on the surface of structured reactors. However, some methods concern only the oxide deposition (which can further be impregnated by a catalyst precursor) and other concern the direct deposition of a noble metal on substrate, without any oxide layer. The structured reactors than can be coated thanks to these methods are presented in the text and summarised in Tables 1 to 6. A wide range of substrates is concerned: silicon microreactors, steel fibres, ceramic monoliths, foams... A comparison of the advantages and drawbacks of the different methods are discussed at the end of the section.

\section{1 (Pre)treatment of the substrate}

The pretreatment of the substrate to coat is gaining more and more importance because it allows to increase the adherence of the catalytic layer and thus the life time of the strcutured catalyst. The evolution is for example clearly seen in the work of $\mathrm{Wu}$ et al. Five years ago, the pretreatment consisted of a chemical treatment and a mechanical roughening of the FeCrAl substrate [11]. Recently, a more complex pretreatment has been carried out, including a chemical treatment, an aluminizing treatment and a boehmite primer deposition [12]. The deposited layer was very resistant to ultra-sonic vibration test. In this paragraph are only mentioned some pretreatment methods which may allow to directly impregnate the substrate with a catalyst precursor, by forming an oxide layer or by creating anchoring sites. Plasma oxidative treatment 
used for silicon substrates but also for stainless steel (see for example $[13,14]$ ) and UV treatments are not detailed.

\section{Anodic oxidation}

The anodic oxidation method is generally applied to structures containing aluminum with the objective to obtain a porous alumina layer at the surface $[15,16]$. When applying a direct current (or a direct voltage) to an electrolyte in contact with an aluminum surface, there is a competitive formation of an oxide layer and dissolution of the substrate, generating a porous layer. The temperature must be carefully controlled since the process is exothermic and temperature favours the dissolution rate. The method is either used as a pretreatment before another coating method [17], or as a way to obtain a thin porous layer than can be directly impregnated [17-20]. Trying to increase the porous density of the alumina layer obtained by anodic oxidation, Ganley et al. found that the lowest anodization potential (30V in their comparative experiments) and highest oxalic acid concentration $(0.6 \mathrm{M})$ were the best process conditions. The surface area of the obtained alumina layer can be further increased by a hydrothermal-thermal treatment allowing to reach a surface area of $25 \mathrm{~m}^{2} / \mathrm{g}$ [21]. The oxidation of flat substrates in general leads to uniform oxide layers. In the case of aluminum plates $(60 \mathrm{~mm} \times 20 \mathrm{~mm} \times 0.5 \mathrm{~mm})$, Guillou et al. [22] have studied different parameters such as the presence of additives (oxalic acid, acetic acid, magnesium sulfate) to the electrolyte (sulfuric acid), the composition of the support (pure $\mathrm{Al}$ or $\mathrm{AlMg}$ ) and the anodisation duration. Thicknesses from 10 to $70 \mu \mathrm{m}$ have been obtained after anodisation at $200 \mathrm{~A} / \mathrm{m}^{2}$ and $20 \mathrm{~V}$ at $25^{\circ} \mathrm{C}$. As another example, aluminum foils $(50 \mathrm{~mm}$ x $20 \mathrm{~mm} \times 1 \mathrm{~mm})$ were anodized in sulphuric acid medium $(400 \mathrm{~g} / \mathrm{l})$ for $4 \mathrm{~h}$ under direct current near $0^{\circ} \mathrm{C}$. It resulted in 65 microns thick of $\mathrm{Al}_{2} \mathrm{O}_{3}$ [23]. Ismagilov et al. proposed recently a concept to scale-up the oxidation process, using a heat-exchanger, leading to effective isothermal conditions [24]. Twelve aluminum-containing microstructured substrates can be oxidised simultaneously with an uniform oxide layer. An AlMgSi alloy, in the form of microstructured plates $(20 \mathrm{~mm} \times 26.6 \mathrm{~mm} \times 0.43 \mathrm{~mm})$ was chosen. At different oxidation times the resulting geometry of the channels varies, because of non-uniform alloy composition (and thus different dissolution rates). Using $0.4 \mathrm{M}$ aqueous oxalic acid solution, a current density of $5 \mathrm{~mA} / \mathrm{cm}^{2}$ and at a temperature of $1^{\circ} \mathrm{C}$, a correlation was found between the layer thickness on the microstructured plates and the oxidation time (S-curve). The thickness reaches $65 \mu \mathrm{m}$ after $50 \mathrm{~h}$ oxidation.

The microchannels of assembled microreactors can also be oxidised, thanks to suitable electrode arrangement and electrolyte flow rate [25]. For this demonstration, Wunsch et al. used AlMg microstructured foils and performed the anodic oxidation at constant direct voltage $(50 \mathrm{~V})$ and constant temperature $\left(12^{\circ} \mathrm{C}\right)$. The electrolyte $(1.5 \%$ oxalic acid $)$ was pumped through the mi- 
crostructure at $30 \mathrm{~L} / \mathrm{h}$. Aluminum wires at the inlet and outlet of the channels served as cathods. Following this process, the coated object was rinsed and calcined at $500^{\circ} \mathrm{C}$ and could be further impregnated with a catalyst precursor (Figure 1). The oxide thickness was found to largely depend on the microchannel dimensions. The same anodisation process applied during 6 hours resulted in $7 \mu \mathrm{m}$ thick alumina layer in $15 \mathrm{~mm}$ length microchannels, and only $3 \mu \mathrm{m}$ in 40mm length channels.

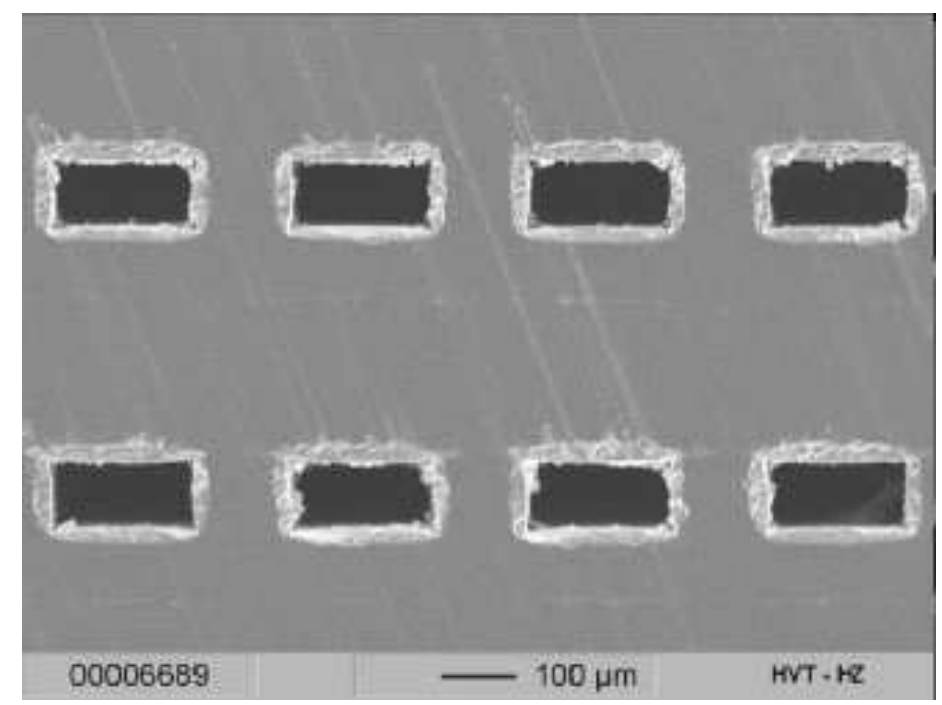

Fig. 1. Anodic oxidation of an AlMg microstructure from [25], reproduced with permission from Wiley-VCH

The same electrolyte bath and process can be used for electrochemical etching to roughen substrate surfaces, e.g. stainless steel 316L surface. This pretreatment modified the smooth steel surface, the microroughness reaching 200$300 \mathrm{~nm}$ [26]. Another example concerns the formation of porous silicon [27].

\section{Thermal oxidation}

Like anodic oxidation, thermal oxidation is not really a deposition method but a surface modification. However, it can be used either as a pretreatment step [10,28-31] to increase the catalyst adhesion or as a catalyst support obtention [32]. It is often applied to FeCrAl substrates. The mechanism of the oxide layer formation at $\mathrm{FeCrAl}$ surfaces by thermal treatment in air has been studied by Camra et al. [33]. During segregation at high temperature $\left(840^{\circ} \mathrm{C}\right)$, aluminum oxides are preferably formed on the upper part of the substrate in the range of $1 \mu \mathrm{m}$ thickness. Giani et al. [34] also found that the optimal oxidation temperature was around $900^{\circ} \mathrm{C}$. FeCrTi have also been pre-oxidized by this way at $850{ }^{\circ} \mathrm{C}$ [35]. However, in the case of FeCrNi wire, the thermal treatment led to the formation of an amorphous iron oxide layer, thus less suitable for catalyst deposition [36]. Thermal oxidation at $1500^{\circ} \mathrm{C}$ has also been used to form a $\mathrm{SiO}_{2}$ layer $(10 \mu \mathrm{m}$ thick $)$ on $\alpha$-SiC substrate [37].

\section{Chemical treatment}


Again used as a pretreatment step, a chemical oxidation of the substrate is sometimes carried out. Valentini et al. [38] first immerse aluminum slabs in $\mathrm{HCl}$ solution to increase the surface roughness and then in $\mathrm{HNO}_{3}$ to favour the formation of a $\mathrm{Al}_{2} \mathrm{O}_{3}$ layer. The $\mathrm{HCl}$ treatment is often used to clean the metallic surfaces [39] but also helps forming a pseudo-layer accessible to chemisorption of small charged particles [40]. Concerning silicon and titanium based substrates, etching and/or oxidation of the surface can be obtained by an alkali treatment [41].

\subsection{Coating methods based on a liquid phase}

\section{Suspension}

All methods based on the dispersion of a finished material (catalyst support or catalyst itself) have been gathered under the term "suspension method". In some preparations, the difference with sol-gel method is tiny because the suspension method often implies some gelification steps. It is the most largely used method, namely for ceramic monoliths. Thus, all the reviews concerning monolith coating give the details of this method [7]. Only some basics are recalled here as well as specific measures which make this method adaptable to other supports than ceramic monoliths. Powder (catalyst support or catalyst itself), binder, acid and water (or another solvent) are the standard ingredients. The concentration of all ingredients varies largely from one experimentator to another and also depends on the nature of the surface to coat and on the desired layer thickness. The size of the suspended particles has a great influence on the adhesion on the susbstrate, as demonstrated by Agrafiotis et al. in the case of monolith coating by different oxides. Particles size diameter in the range $2 \mu \mathrm{m}$ lead to much more adherent layers than 17 or $52 \mu \mathrm{m}$ [42]. Gonzalez-Velasco et al. [43] have studied the influence of crushing and acid addition in the deposition of a catalyst on a cordierite monolith. It was found that a good washcoating of these materials is favoured by particle size distributions preferably below $10 \mu \mathrm{m}$. Nitric acid at pH of 5 was preferred among different acids and resulted in uniform washcoat. Small particles are also advantageously used for non-porous substrates. Zapf et al. [44,45], for ex-

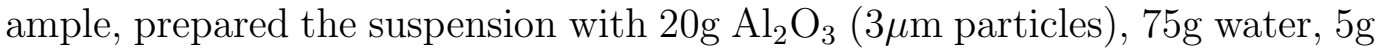
polyvinyl alcohol and $1 \mathrm{~g}$ acetic acid and obtained a very adherent $\mathrm{Al}_{2} \mathrm{O}_{3}$ layer on stainless steel microchannels. Very good description of the role of binder, surfactant, viscosity modifier are given in the publication of Agrafiotis et al. and the review of Avila et al. concerning the coating of ceramic honeycombs $[46,8]$. It is interesting to notice that the suspension method allows to deposit ready-to-use (e.g. commercially available) catalysts. Valentini et al. [38,34] use the same method to deposit $\mathrm{Al}_{2} \mathrm{O}_{3}$ or a ready-to-use catalyst. It consists in depositing a primer made of boehmite sol, then after calcination, depositing a ball milled slurry containing the powder $\left(\mathrm{Al}_{2} \mathrm{O}_{3}\right.$ or catalyst), water and ni- 
tric acid. Sometimes, a viscosity modifier is added, as seen for example in the work of Jiang et al. [47] to deposit $\mathrm{Pt} / \mathrm{TiO}_{2}$ catalyst on $\mathrm{Al} / \mathrm{Al}_{2} \mathrm{O}_{3}$-coated wire meshes and that of Chung et al. [48] to coat cordierite and wire-mesh monoliths with $\mathrm{TiO}_{2}$. In the latter case, the slurry was heated at $60{ }^{\circ} \mathrm{C}$ during $2 \mathrm{~h}$ before dip-coating. No details of the suspension is given. In the case of Pfeifer et al. [3,49], the suspension contained a cellulose derivative (1wt- $\%$ of hydroxy ethyl (or propyl) cellulose) and a solvent (water or isopropyl alcohol). The nanoparticles (20wt-\% in the suspension) of $\mathrm{CuO}, \mathrm{ZnO}$ and $\mathrm{TiO}_{2}$ or $\mathrm{Pd} / \mathrm{ZnO}$ catalyst were mixed together with this solution. The cellulose derivative was found to efficiently avoid the particles agglomeration [50]. The resulting suspension was filled into microchannels, dried and calcined at $450^{\circ} \mathrm{C}$. A complete burn off of the polymer was obtained (Figure 2). An organic dispersant (terpineol and ethyl cellulose) was also used by Choi et al. [51] to deposit a $\mathrm{Pt} / \mathrm{Al}_{2} \mathrm{O}_{3}$ catalyst on a silicon substrate $(10-30 \mu \mathrm{m}$ thick $)$. Some preparations

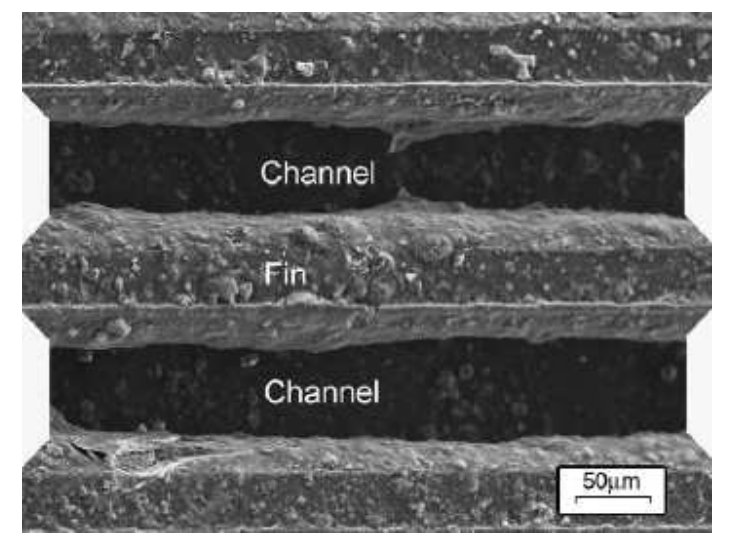

Fig. 2. Catalyst coating in microchannels (Reprinted from [3] with permission from Elsevier)

only contain oxide powder and solvent. Whereas this is not currently the case for the coating of non-porous substrates [52,29], many examples can be found for ceramic coating. For example, Liguras et al. prepared a dense suspension of catalyst $\left(\mathrm{Ni} / \mathrm{La}_{2} \mathrm{O}_{3}\right)$ powder in de-ionized water. A simple immersion of ceramic substrates in the suspension followed by drying at $120^{\circ} \mathrm{C}$ and calcinations $\left(550^{\circ} \mathrm{Cand} 1000^{\circ} \mathrm{C}\right)$ allowed to obtain the catalytic material [53]. A simple mixture of oxides in water is also used by Ding et al. [54], Boix et al. [55], Kikuchi et al. [56] to cover a ceramic monolith.

In one study, the catalyst was not deposited on a structured support but as a tape which can be rolled in the desired shape [57]. Gd-doped $\mathrm{CeO}_{2}$ with 0.5 wt- $\%$ Pt was used as the catalyst material and was dispersed by using commercial dispersion agents and solvents, xylenes and alcohols. The dispersed catalyst slurry was mixed with organic binder resins such as polyvinylbutyral or acryloid. The final slurry was cast at the desirable thickness $(50-200 \mu \mathrm{m})$ with a blade and subsequently dried in air. 
Sol-gel deposition

Under this term are gathered various methods [58]. The starting point is a solution (or a colloidal dispersion) of a chemical precursor of the material to deposit. One important factor in sol-gel technology is the ageing time allowing the gelation (peptisation) of the sol. It can vary from a few minutes to several weeks, depending on the concentrations in the sol and the characteristic size of the object to coat. The conditions during sol formation have to be chosen in order to obtain oligomers with desired degree of branching. Sol with high viscosities, obtained after long ageing time, allow to deposit thicker layer but are exposed to cracks. A compromise has to be found for each preparation and substrate to coat. For example, to deposit alumina, the precursor of the sol can be :

- Hydrated aluminum oxides (pseudo-boehmite or boehmite) $[59,60]$

- Aluminum alkoxides $[58,61]$.

- Aluminum chloride + aluminum [58]

Other supports than alumina can be deposited [62]. For example, Ligura et al. [53] have tested a sol-gel prepared using $\mathrm{Al}\left[\mathrm{OCH}\left(\mathrm{CH}_{3}\right)_{2}\right]_{3}, \mathrm{Ni}\left(\mathrm{NO}_{3}\right)_{2} \cdot 6 \mathrm{H}_{2} \mathrm{O}$ and $\mathrm{La}\left(\mathrm{NO}_{3}\right)_{3} \cdot 6 \mathrm{H}_{2} \mathrm{O}$ as precursors. Monoliths or foams were immersed in the sol-gel without any other pretreatment, removed and dried at $120^{\circ} \mathrm{C}$. A final calcination at $550^{\circ} \mathrm{C}$ completed the preparation. Richardson et al. [63] also added lanthanum nitrate to their preparation, to avoid $\mathrm{Al}_{2} \mathrm{O}_{3}$ to transform to alpha alumina. The other ingredients are boehmite, aluminum nitrate, water and glycerol (viscosity modifier). Tonkovitch et al. [64] prepared a $\mathrm{ZrO}_{2}$ layer on $\mathrm{Ni}$ foams from zirconium alkoxide in acidic solution. $\mathrm{SiO}_{2}$ was also often deposited on surfaces, namely glass and silicon ones starting from silicon alkoxides $[65,66]$. For the synthesis of sol-gel derived $\mathrm{TiO}_{2}$, the precursors have to be partially hydrolyzed in a very controlled manner, such that subsequent polycondensation reactions yield a weakly branched polymeric metal oxide sol. To deposit $\mathrm{TiO}_{2}$, Giornelli et al. [23] solubilized tetrabutyl orthotitanate $\mathrm{Ti}(\mathrm{OBu})_{4}$ in dry propyl-alcohol at room temperature. After hydrolysis, the $\mathrm{Al}_{2} \mathrm{O}_{3} / \mathrm{Al}$ plates to coat were immersed under stirring for $1 \mathrm{~h}$ and withdrawn using a home-made apparatus at $6 \mathrm{~mm} / \mathrm{s}$. A very similar method is also used by Danion et al. to coat optical fibres [67]. Important details on the influence of the $\mathrm{pH}$ and the calcination temperature of the above titanium sol on the crystalline phase are given in the study of Yates et al [68]. It is also possible to use sol-gel method to directly obtain an alumina supported noble metal. Ioannis et al. [69] have mixed an aluminum isopropoxide sol with a rhodium nitrate solution in nitric acid; Kurungot et al. [70] have mixed rhodium chloride and poly(vinyl alcohol) with a boehmite sol; Chen et al. [71] have mixed an aluminum isopropoxide sol with $\mathrm{H}_{2} \mathrm{PtCl}_{6}$ in butanediol. It should be noted than in recent years, oxide thin films with a meso ordered framework have been synthesized according to several methods (based on sol-gel preparation) detailed by e.g. Huesing et al. for silica [72] or Fajula et al. for other materials 
[73]. For example, by the solvent evaporation-induced self-assembly (EISA) method, silicon wafers have been coated with $\mathrm{SiO}_{2}-\mathrm{TiO}_{2}, \mathrm{SiO}_{2}-\mathrm{ZrO}_{2}$ and $\mathrm{SiO}_{2}-\mathrm{Ta}_{2} \mathrm{O}_{5}$ catalytic films with a thickness of 200-300nm [72]. The starting materials comprised metal alkoxide with oligo(ethylene oxide) alkylether surfactants as structure-directing agents enabling the formation of ordered mesophases with high surface areas.

\section{Hybrid method between suspension and sol-gel}

The method does not differ very much from suspension method. In the present case, a sol acts as the binder, but also participates in the chemical and textural properties of the final deposited layer. For example, to obtain a silica layer, metallic monoliths have been dipped in a suspension of silica powder (0.7$7 \mu \mathrm{m})$ with a silica sol. The layer obtained after drying and calcination steps is $20-50 \mu \mathrm{m}$ thick [74]. The same mixture porous oxide powder/sol is also used for alumina deposition $[75,76]$ (Figure 3). Some studies have demonstrated that the use of more or less completely dissolved binders (or binders consisting of nanometer-sized particles) like pseudo-boehmite or sodium silicate (waterglass) was not recommended, because of the possible covering of active regions [7]. Groppi et al. actually found that washcoats resulting from catalysts suspended in sodium silicate solution or in a silica sol had lower activity than from catalysts dispersed in aqueous acid solution [77]. The textural properties of catalytic layers obtained from suspension in a solution of sodium silicate reveal very low porosity and specific surface area [78]. However, in the recent

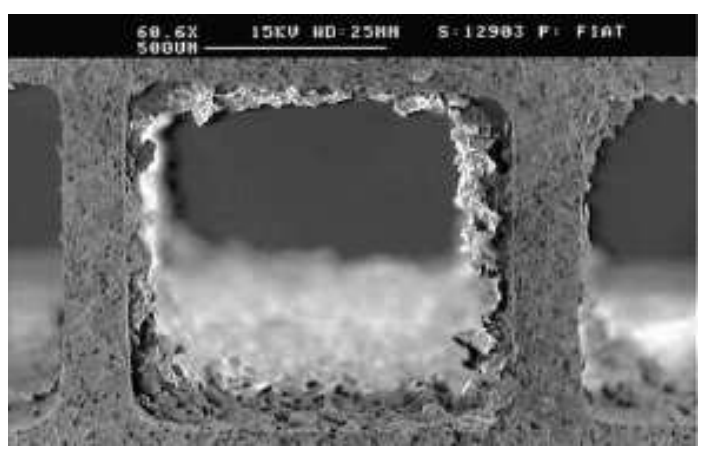

Fig. 3. Hybrid method suspension/sol-gel: monolith coated with $\mathrm{Al}_{2} \mathrm{O}_{3}$ powder dispersed in colloidal ceria sol (reprinted from [76] with permission from Elsevier)

years (2003-2006), many examples of hybrid preparation have been published and the catalysts seemed to present good activities. Seo et al. [35] have deposited some zirconia on a pre-oxidized FeCrTi fin-tube. The $\mathrm{ZrO}_{2}$ sol was prepared by dissolving zirconium alkoxide with nitric acid. The sol was mixed with $\mathrm{ZrO}_{2}$ powder, resulting in the formation of the slurry. After thoroughly stirring the slurry, the tube was dip-coated into the slurry containing $\mathrm{ZrO}_{2}$. After drying during 6 hours, the tube was activated at $850^{\circ} \mathrm{C}$ to form the zirconium oxide layer on the surface. The same authors also used a mixture of $\mathrm{CuO} / \mathrm{ZnO} / \mathrm{Al}_{2} \mathrm{O}_{3}$ catalyst with alumina sol to coat stainless steel sheets [80]. Germani et al. [81] compared the layer obtained from pure sol-gel with 


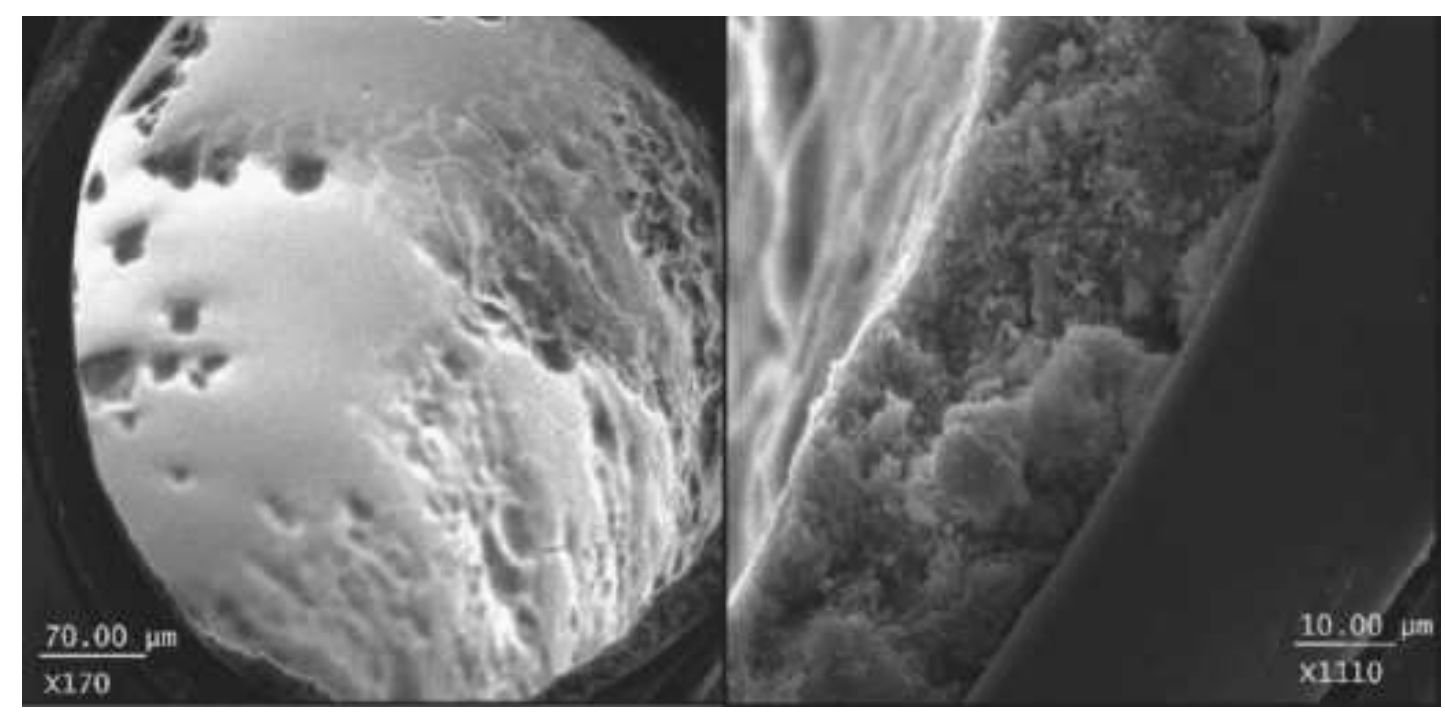

Fig. 4. Deposition of $\mathrm{CuO} / \mathrm{ZnO} / \mathrm{Al}_{2} \mathrm{O}_{3}$ on the internal wall of $530 \mu \mathrm{m}$ capillaries (reprinted from [79] with permission from Elsevier)

that obtained from the hybrid method. The first step comprised the preparation of an aluminum hydroxide sol-gel from aluminum tri-sec-butoxide. The platinum precursor $\left(\mathrm{H}_{2} \mathrm{PtCl}_{6} \cdot 6 \mathrm{H}_{2} \mathrm{O}\right)$ in water was added for hydrolysis and simultaneous catalyst incorporation. The ceria precursor $\left(\mathrm{Ce}\left(\mathrm{NO}_{3}\right)_{3} \cdot 6 \mathrm{H}_{2} \mathrm{O}\right)$ in water was added after peptization. In the hybrid method, catalyst powder is added. This catalyst comes from the calcination of a part of the sol. The pure sol-gel method produced layers of about $1 \mu \mathrm{m}$ thick whereas the hybrid one allowed to get layer thicker than $10 \mu \mathrm{m}$. Both catalysts, deposited on stainless steel microchannels, were active in the conversion of carbon monoxide; their activity was higher than a powder catalyst due to diffusion improvement. In the study of Tadd [31], to prepare the washcoat, the catalyst was mixed with water, polyvinyl alcohol, and a ceria-zirconia binder prepared from pure support. The mixture was ball-milled with zirconia grinding media for $48 \mathrm{~h}$, resulting in a uniform slurry used to coat FeCrAl foams. Woo et al. $[82,83]$ mix a commercial catalyst $\left(\mathrm{CuO}-\mathrm{ZnO}-\mathrm{Al}_{2} \mathrm{O}_{3}\right)$ with a zirconia sol (from zirconium isopropoxide) and isopropyl alcohol to coat stainless steel plates and microchannels. For Karim et al. [84,79], the typical slurry formulation consisted of $100 \mathrm{ml}$ water, $25 \mathrm{mg}$ of $\mathrm{CuO} / \mathrm{ZnO} / \mathrm{Al}_{2} \mathrm{O}_{3}$ catalyst, $10 \mathrm{mg}$ of boehmite and $0.5 \mathrm{ml}$ of nitric acid. It was rotated overnight, during which time gelation of the sol occurs. The sol-gel slurry was coated onto the walls of the capillaries using the gas displacement method (Figure 4). In the work presented by Walter et al. [85], the $\mathrm{V}_{75} \mathrm{Ti}_{25} \mathrm{Ox}$ catalyst was mixed with a filtered sodium silicate aqueous solution (sodium has been removed by ion exchange) and applied onto aluminum microchannels.

Deposition on structured objects from suspension, sol-gel or hybrid methods In general, the suspension and the sol-gel are applied to the structured object by dip-coating [60]. An alternative to dip-coating is spray-coating. Instead of 
immersing the structure in a slurry, a spray of the suspended powder is applied [86]. The properties of the suspension differ from that used for dip-coating, namely viscosity since the shear rate is many times larger during spraying than immersing. As an example, Sidwell et al. prepare a suspension (hybrid) containing a commercial catalyst $\left(\mathrm{Pd} / \mathrm{Al}_{2} \mathrm{O}_{3}\right)$, an aluminum oxide (Catapal D) and acetone (acetone/powder ratio $=4 / 3$ ) [87]. Several layers are applied by spraying till the desired thickness. Acetone is removed by nitrogen flowing between each sprayed layer. A calcination is carried out at the end of the coating. In that example, the spray is applied to a cast-alumina disk. Spraying is well-adapted to the coating of fibres [59]. Wu et al. [11] used both spraycoating (plasma spraying) and dip-coating methods to apply suspensions on $\mathrm{FeCrAl}$ mesh. The same thickness was obtained with both methods but starting from different suspensions: suspended alumina with polyvinyl alcohol and water for plasma-spray coating, suspended alumina in a boehmite sol (hybrid method) for dip-coating. The spray-coated layer was found to be more adhesive. In the case of coating deposited before microreactor assembling, drops of the sol-gel can be deposited (drop-coating) with a possible simultaneous heating of the microreactor channels [88]. Spin-coating can also be used for wafers (microstructured or not) [66,60]. According to this deposition method, a correlation between the film thickness, the sol viscosity and the spin speed was proposed by Huang et al. [89]. Less predictible method such as the use of a brush to deposit the liquid as a thin layer is also possible [85]. In closed micro-channel (assembled micro-reactor or capillaries), the deposition can be performed by infiltration of the sol-gel [71] or gas fluid displacement, which consists in filling the capillary with a viscous fluid, and clearing the capillary by forcing gas through it [79]. On the contrary, in the example detailed by Janicke et al. [90], the excess fluid was not removed. Microchannels were filled with an aluminum hydroxide solution $\left(\mathrm{pH}=5.8,1.70 \% \mathrm{Al}_{2} \mathrm{O}_{3}\right)$, which was allowed to slowly dry over a $24 \mathrm{~h}$ period, and then calcined at $550^{\circ} \mathrm{C}$. Electrostatic sol-spray deposition has been used on aluminum surfaces to spray zinc acetate or zirconium propoxide sols [91] or on stainless steel to spray a titanium tetrahydropropoxide sol [92]. By combining the generation of a charged aerosol and the heating of the substrate to coat $\left(100-200^{\circ} \mathrm{C}\right)$, an easy control of the morphology of the deposited layer was obtained.

\section{Electrophoretic deposition (EPD)}

EPD is a colloidal process wherein a direct current (DC) electric field is applied across a stable suspension of charged particles attracting them to an oppositely charged electrode [93]. One electrode (cathode) consists of the substrate to coat, the anode being either an aluminum foil [94] or stainless steel [95]. The thickness of the coating depends on the distance between the two electrodes (ca. $10 \mathrm{~mm}$ ), the DC voltage (can vary from 10 to $300 \mathrm{~V}$ ), the properties of the suspension (e.g. $\mathrm{pH}$ ) and the duration. This technic is often used to deposit a layer of aluminum oxide (by oxidation of an aluminum layer) as a pre-coating, to favour the adhesion of a catalyst, deposited in a second time by dip-coating 
in a suspension [95,47]. For example, Yang et al. [95] used aluminum powder of $5 \mu \mathrm{m}$ diameter as the suspension's particles. Polyacrylic acid and aluminum isopropoxide were used as additives, and expected to improve the adhesion of aluminum particles and control the suspension conductivity, respectively. The substrate to coat was stainless steel wire mesh. EPD allowed to deposit $100-120 \mu \mathrm{mAl}$ on the substrate which was further oxidised to form a porous $\mathrm{Al}_{2} \mathrm{O}_{3}$ layer $\left(12 \mathrm{~m}^{2} / \mathrm{g}_{\text {wire }}\right)$ This technique can also be used to obtain a highly porous catalytic support [94]. Vorob'eva et al. used alumina sol (from hydrolysis of aluminum isopropoxide) for particle suspension during electrophoretic deposition. After drying and calcination, they obtained a very regular layer of aluminum oxide on their stainless steel gauze, with a high BET specific surface area $\left(450 \mathrm{~m}^{2} / \mathrm{g}\right)$. In the case of Wunsch et al. [25], microchannels had to be coated. $\mathrm{Al}_{2} \mathrm{O}_{3}$ nanoparticles in water were used and the properties (viscosity, conductivity) of the liquid medium were varied (glycerol, oxalic acid, aluminum oxide gel). It was found that a colloidal suspension of $\mathrm{Al}_{2} \mathrm{O}_{3}$ in oxalic acid led to an insufficient adhesion, whereas the addition of an alumina gel or of glycerol allows to obtain adhesive layers of 2 to $4 \mu \mathrm{m}$ thick [50].

\section{Electrochemical deposition and electroless plating}

Electrochemical deposition and electroless plating use ionic solutions. The first method, also called "electroplating" or simply "electrodeposition", produces a coating, usually metallic, on a surface by the action of electric current. The deposition of a metallic coating onto an object is achieved by putting a negative charge on the object to be coated (cathode) and immersing it into a solution which contains a salt of the metal to be deposited. When the positively charged metallic ions of the solution reach the negatively charged object, it provides electrons to reduce the positively charged ions to metallic form. This method has been used by Lowe et al. to deposit a silver film on stainless steel microreactors [96]. Stefanov et al. [26] obtained a layer of $\mathrm{ZrO}_{2}$ on stainless steel, starting from a $\mathrm{ZrCl}_{4}$ alcoholic solution. The electrolysis time was varied from 3 to 120 minutes. The voltage varied from 3 to $9 \mathrm{~V}$ and the temperature was fixed $\left(25^{\circ} \mathrm{C}\right)$. A successive deposition of $\mathrm{La}_{2} \mathrm{O}_{3}$ was also performed by immersing the $\mathrm{ZrO}_{2}$ coated object in a solution containing $\mathrm{LaCl}_{3}$ [97]. The resulting catalyst presents a BET specific surface of $20 \mathrm{~m}^{2} / \mathrm{g}$. The method has also been applied by Fodisch et al. to deposit the metal catalyst on an alumina layer [16]. A palladium electrolyte made of $\mathrm{Pd}\left(\mathrm{SO}_{4}\right)$, boric acid, citric acid and water is applied at $25^{\circ} \mathrm{C}, 7.5 \mathrm{~V}, 50 \mathrm{~Hz}$ for 3 minutes. Then, the catalyst is calcined. The method is in the present case an alternative to impregnation but presents the drawback that an important ratio of palladium is deposited at the pore base (not available to chemical reaction) [16]. Electroless plating uses a redox reaction to deposit a metal on an object without the passage of an electric current. According to this method, Fukuhara et al. [98,99] prepared a copper-based catalyst on an aluminum plate. The plate was first immersed in a zinc oxide plating bath to displace surface aluminum with zinc. Subsequently, the plate was immersed in plating baths of iron. Finally, it was immersed in 
a copper plating bath based on $\mathrm{Cu}\left(\mathrm{NO}_{3}\right)_{2}$. The bath contained formaldehyde solution as a reducing agent. The successive platings allow to obtain a better adhesion because of small differences between standard potential electrodes.

\section{Impregnation}

The deposition of the catalyst support on structured objects can be performed by impregnation in the case of ceramic (macroporous) structures. Ahn et al. [100] have immersed a monolith in solutions of aluminum or cobalt nitrate to obtain, after calcination, a layer of $\mathrm{Al}_{2} \mathrm{O}_{3}$ or $\mathrm{Co}_{3} \mathrm{O}_{4}$ that have been further impregnated with an active metal precursor. The direct impregnation of the structured object by catalyst precursors (without any porous support) is sometimes the only realistic way for some objects to become catalytic. In the case of glass fibres cloths of different weaving modes, Matatov et al. have perform a direct impregnation with Pd by ion-exchange method [101]. This direct impregnation is justified because the specific surface area of glass fibres can amount up to $400 \mathrm{~m}^{2} / \mathrm{g}$. Reymond propose the direct impregnation of stainless steel grids and carbon fabrics with palladium chloride as a simplest way to obtain a structured catalyst [39]. Again, concerning carbon fabrics, its high specific surface area makes a preliminary support deposition unnecessary. $\beta$-SiC structured objets prepared by Ledoux et al. [102] do not require a washcoat since the surface area is appr. $50-100 \mathrm{~m}^{2} / \mathrm{g}$. Different catalysts have been deposited on the $\mathrm{SiC}$ structures $\left(\mathrm{Pt}-\mathrm{Rh}, \mathrm{NiS}_{2} \ldots\right.$ ) by traditional catalyst preparation methods. Nevertheless, most of the time, the impregnation follows either a anodisation step, an oxide deposition... or other methods to obtain a catalytic support [60] and thus does not differ from traditional catalysis. In the work of Suknev et al. [40], silica fibreglass $(7-10 \mu \mathrm{m}$ thick) have been impregnated with platinum chloride or ammonia complexes. In that case, the acidic $(\mathrm{HCl})$ pretreatment of the silica, even if it did not reveal a porous layer, allowed the chemisorption of small charged species into the bulk of the glass fibres. $0.03 \mathrm{wt}-\% \mathrm{Pt}$ on the fibreglass was obtained.

\subsection{Other ways}

Techniques for electronic oxide films growth have been reviewed by Norton [103]. Although this review does not concerns catalysis, the description of the different techniques is common to catalytic oxide films deposition in dry way. The technical details of the methods can be found there. In the following paragraphs, the examples chosen concern catalyst deposition.

\section{CVD}

The chemical vapor deposition technique requires the use of chemical precursors of the desired deposited material. The chemical precursor can be the same than used in sol-gel methods (e.g. aluminum alkoxide) but no solvent 
is required. Only the volatile precursor and the structured object are present in the deposition chamber. To enhance the deposition rate, the use of low pressures and high temperatures may be required. PACVD (plasma assisted CVD) also allows to perform the deposition at lower temperature and higher deposition rate [104]. Such methods have been used for many other applications than catalysis but we will only deal with this last point. Moreover, as CVD can be used to deposit catalyst on a powder substrate [60] or on carbon nanotubes, only deposition on geometric structures will be considered. Aluminum isopropoxide was used by Janicke et al. [90] for the production of aluminum oxide coatings in stainless steel micro-channels, before the impregnation with a platinum precursor (Figure 5). Molten $\mathrm{Al}(\mathrm{OiPr})_{3}$ was kept at a constant temperature of $160^{\circ} \mathrm{C}$ in a glass bubbler through which $1 \mathrm{~L} / \mathrm{min}$ of $\mathrm{N}_{2}$ was passed. This $\mathrm{N}_{2} / \mathrm{Al}(\mathrm{OiPr})_{3}$ was mixed with $\mathrm{O}_{2}$ flowing at $7 \mathrm{~L} / \mathrm{min}$. Oxygen was necessary for the decomposition of the alkoxide and to prevent the buildup of carbon in the reactor. Following mixing, the combination of gases passed through the $140 \times 200$ microns channels in the reactor at $300^{\circ} \mathrm{C}$ for $1 \mathrm{~h}$. In the example presented by Chen et al. [105], $\mathrm{Mo}_{2} \mathrm{C}$ thin films were formed on $\mathrm{Si}$ surfaces. It was demonstrated that a simultaneous heating of the chemical precursor $\left(\mathrm{Mo}(\mathrm{CO})_{6}\right)$ and the silicon substrate was necessary to obtain a nano-structured thin film. The deposition was performed at $0.2 \mathrm{mbar}$ and $600{ }^{\circ} \mathrm{C}$. It should be noted that ALD (atomic layer deposition), also called ALE (E for epitaxy), is a modification to the CVD process consisting in feeding the precursors as alternate pulses that are separated by inert gas purging. The thickness of the deposited layer linearly depends on the number of cycles. This modern method allows to obtain uniform films. For example (not in the catalysis field), Aaltonen et al. [106] deposited in two successive steps an alumina film and a platinum layer on a $5 \mathrm{~cm}$ square borosilicate glass substrate. The film was uniform, with a thickness varying from 60 to $65 \mathrm{~nm}$ all over the substrate. This method was used for catalyst preparation [107] and also to deposit an intermediate oxide layer before zeolite deposition on microstructured reactors [108].

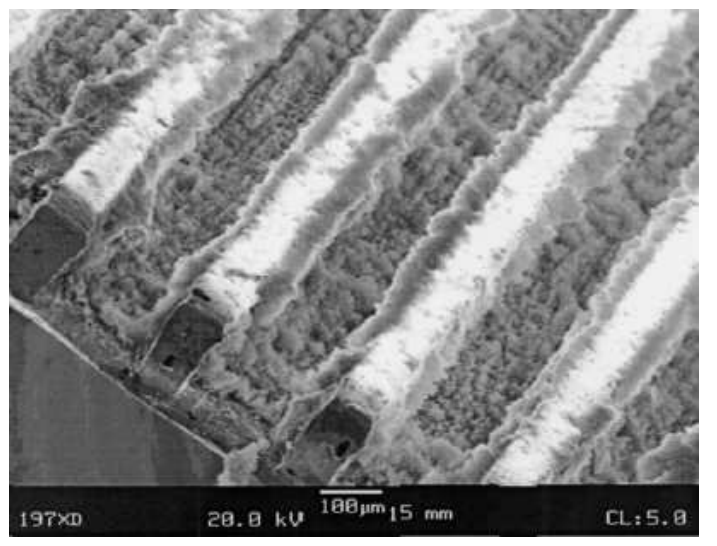

Fig. 5. Deposition of $\mathrm{Al}_{2} \mathrm{O}_{3}$ by CVD in stainless steel micro-channels (reprinted from [90] with permission from Elsevier) 
Physical Vapor Deposition (PVD)

This term includes a mechanical method (cathodic sputtering), and thermal methods (evaporation and electron-beam evaporation). The equipments required for such deposition methods are available at microelectronics fabricants and often concerns silicon coatings.

Cathodic sputtering: A capacitive plasma is generated between the surface to coat and a target made of the material to be deposited. Sputtering is performed under vacuum, the structured surface is operated as the anode and the coating material is operated as the cathode which emits atoms to the surface. The catalytic metal $(\mathrm{Pd}, \mathrm{Pt}, \mathrm{Cu})$ is often sputtered without a prior oxide layer [4,109-113]. Glass fabrics have also been coated this way with platinum [114]. The PVD method also allows to deposit i) a catalyst on a porous support (e.g. Pt or Au sputtered on porous silica [66,13], Ag sputtered on oxidised FeCrAl microchannels [115]), ii) the desired amount of support (e.g. Ti [41]). In the latter case, the support can be further treated to make it porous (by oxidation).

Electron-beam evaporation: In electron beam evaporation, a high kinetic energy beam of electrons is directed at the material for evaporation. Upon impact, the high kinetic energy is converted into thermal energy allowing the evaporation of the target material $[116,117]$. In the example presented by Srinivasan et al. [116], platinum is coated on silicon wafers (100nm) after the deposition of 10nm $\mathrm{Ti}$ as an adhesion layer.

Pulsed laser deposition (PLD) This process is also known as pulsed laser ablation deposition; a laser is used to ablate particles from a target in a deposition chamber under reduced pressure and at elevated temperature. The number of laser pulses is directly related to the thickness of the film deposited on the substrate. For example, $\mathrm{TiO}_{2} / \mathrm{WO}_{3}$ has been deposited by PLD at $500^{\circ} \mathrm{C}$ on silicon and quartz glass substrates for photocatalytic applications [118]. $\mathrm{Cu}-\mathrm{CeO}_{2}$ thin films with various copper composition were deposited on $\mathrm{Si}$ at $750{ }^{\circ} \mathrm{C}$ in 90 to 360 seconds. Correlations were found between crystalline texture of thin films, copper atom fractions and deposition times [119].

Flame assisted vapor deposition (FAVD), flame spray deposition (FSD) and powder plasma spraying

According to FAVD, the deposition process can take place in an open atmosphere without requiring the use of complex deposition chamber and/or vacuum system like in CVD or PVD methods [120]. The atomised chemical precursor of the catalyst (nitrates of nickel and aluminium in ethanol and water in that case) is burned in a flame. The method can thus be considered as a "dry" way of deposition for the substrate which is placed in the combustion zone, at controlled distance and temperature. The average deposition rate for coatings deposited from 400 to $600{ }^{\circ} \mathrm{C}$ was found to be about $10 \mu \mathrm{m} / \mathrm{min}, 10$ times higher than the CVD and PVD methods. The FAVD was also found to overcome the limitation of the sol-gel technique due to cracking of thick layers. 
A layer of $100 \mu \mathrm{m}$ catalyst was deposited on a stainless steel tube. This method is also called flame pyrolysis and can be used to deposit various oxides like $\mathrm{Fe}_{2} \mathrm{O}_{3}, \mathrm{Co}_{3} \mathrm{O}_{4}, \mathrm{Y}_{2} \mathrm{O}_{3}, \mathrm{CeO}_{2}$ and $\mathrm{Cr}_{2} \mathrm{O}_{3}$ [121]. Flame spray deposition (FSD) of porous nanostructured catalysts is a modification of flame synthesis. It looks like FAVD, since chemical precursors are sprayed in a flame. But in this case, the precursors are decomposed in the flame at $1220^{\circ} \mathrm{C}$ and the surface to coat is maintained at low temperature $\left(50{ }^{\circ} \mathrm{C}\right)$ [122]. Powder plasma spraying was developed by Ismagilov et al. to coat structured objects $[123,124]$. This method is not related to traditional spraying which depends on the preparation of a suspension or a sol-gel. In the present case, the oxide powder is directly deposited as a dry way. Alumina powders differing in phase composition and particle size (10 to more than 500 micrometres) were injected in a plasma torch, forming a spray used to coat titanium plates and nickel foam materials. Pranevicius et al. $[125,126]$ have used a plasma gun to deposit $\mathrm{Al}_{-} \mathrm{Al}_{2} \mathrm{O}_{3}$ coatings on steel sheets. The distance between the plasma gun and substrate was $100 \mathrm{~mm}$. The steel sheets were rotated during deposition. In that case, the method is called "reactive plasma spraying" because aluminum particles are oxidised in the air plasma. $\mathrm{Al}(\mathrm{OH})_{3}$ is mixed to the aluminum powder; $\mathrm{CuO}$ and $\mathrm{Cr}_{2} \mathrm{O}_{3}$ have also been added in some experiments. The particle size is approximately $50 \mu \mathrm{m}$. Well-adhering coatings consisting of $70 \% \mathrm{Al}_{2} \mathrm{O}_{3}$ present a specific area of $100-120 \mathrm{~m}^{2} / \mathrm{g}$.

\subsection{Comparison of the results obtained with different methods - which method for which application}

Tables 1 to 6 present the methods used by different authors to coat structures of different material and characteristic size. Note that some of the methods cited in the tables have not been described in this paper because not widely used, e.g. the formation of Raney metals on Ni and Co surface. Some details can be found in the literature cited in the tables. 


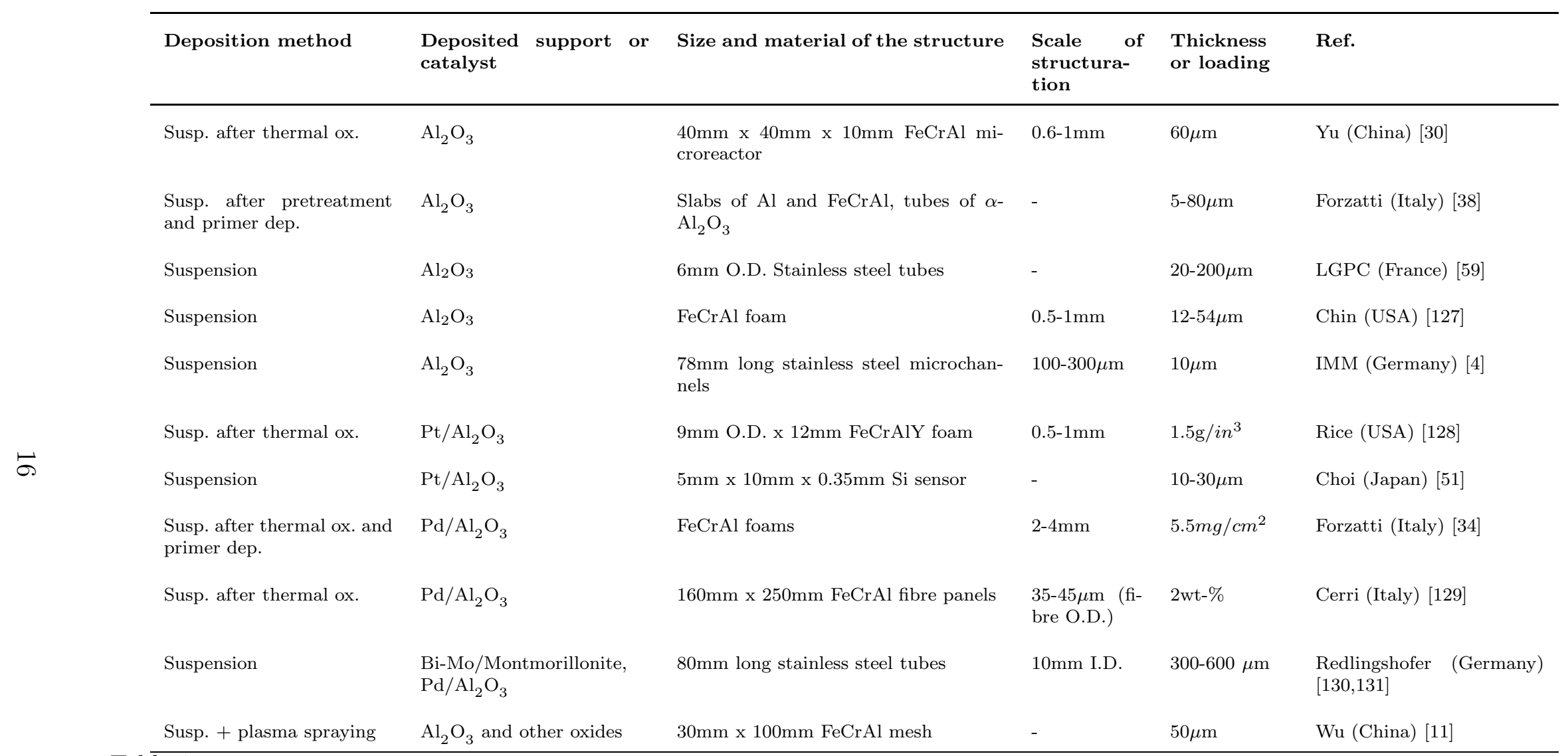

Table 1

Suspension method used to deposit oxides or catalysts on various structures, part I 


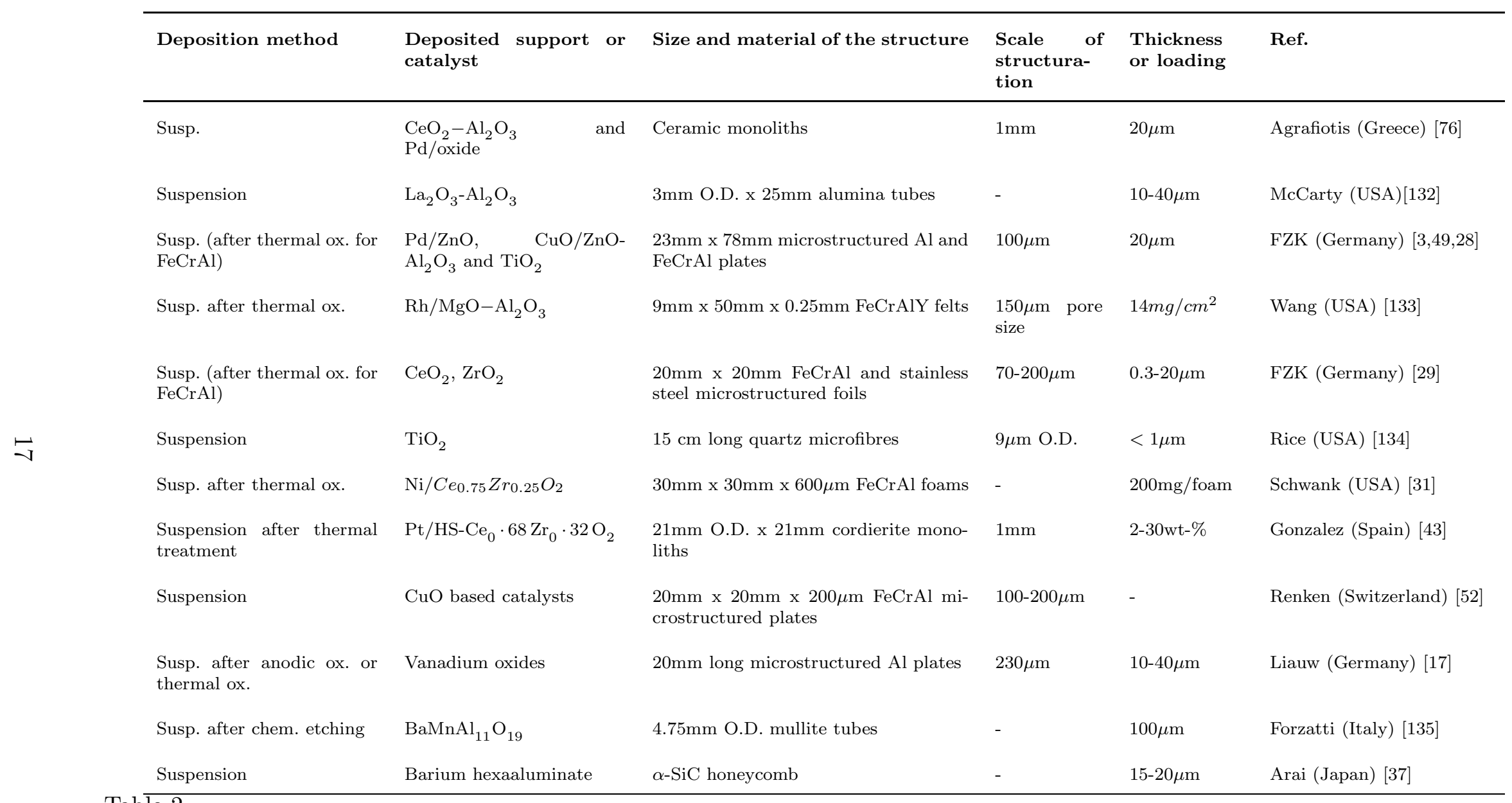

Table 2

Suspension method used to deposit oxides or catalysts on various structures, part II 


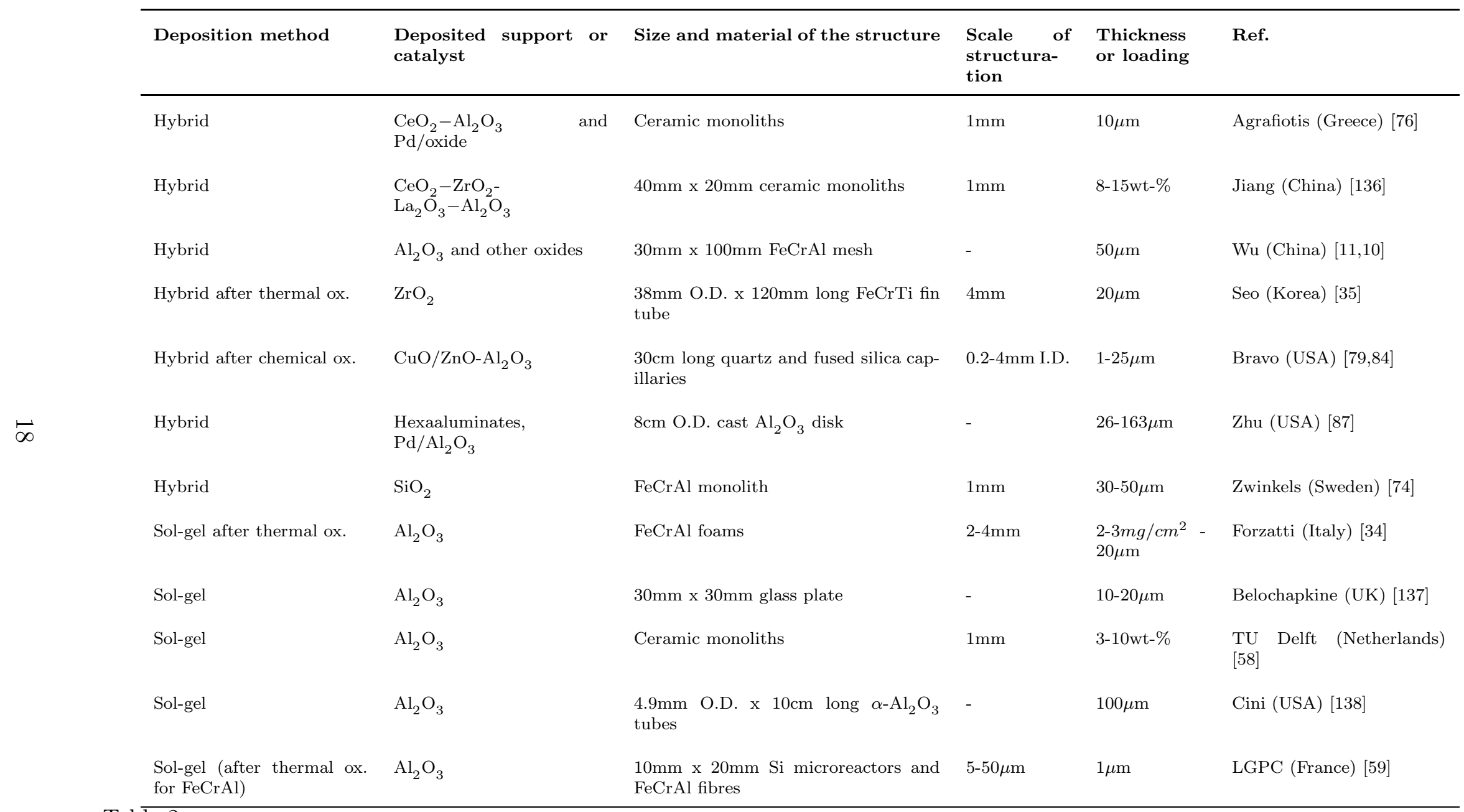

Table 3

Hybrid and sol-gel methods used to deposit oxide or metal-on-oxide catalyst on various substrates 


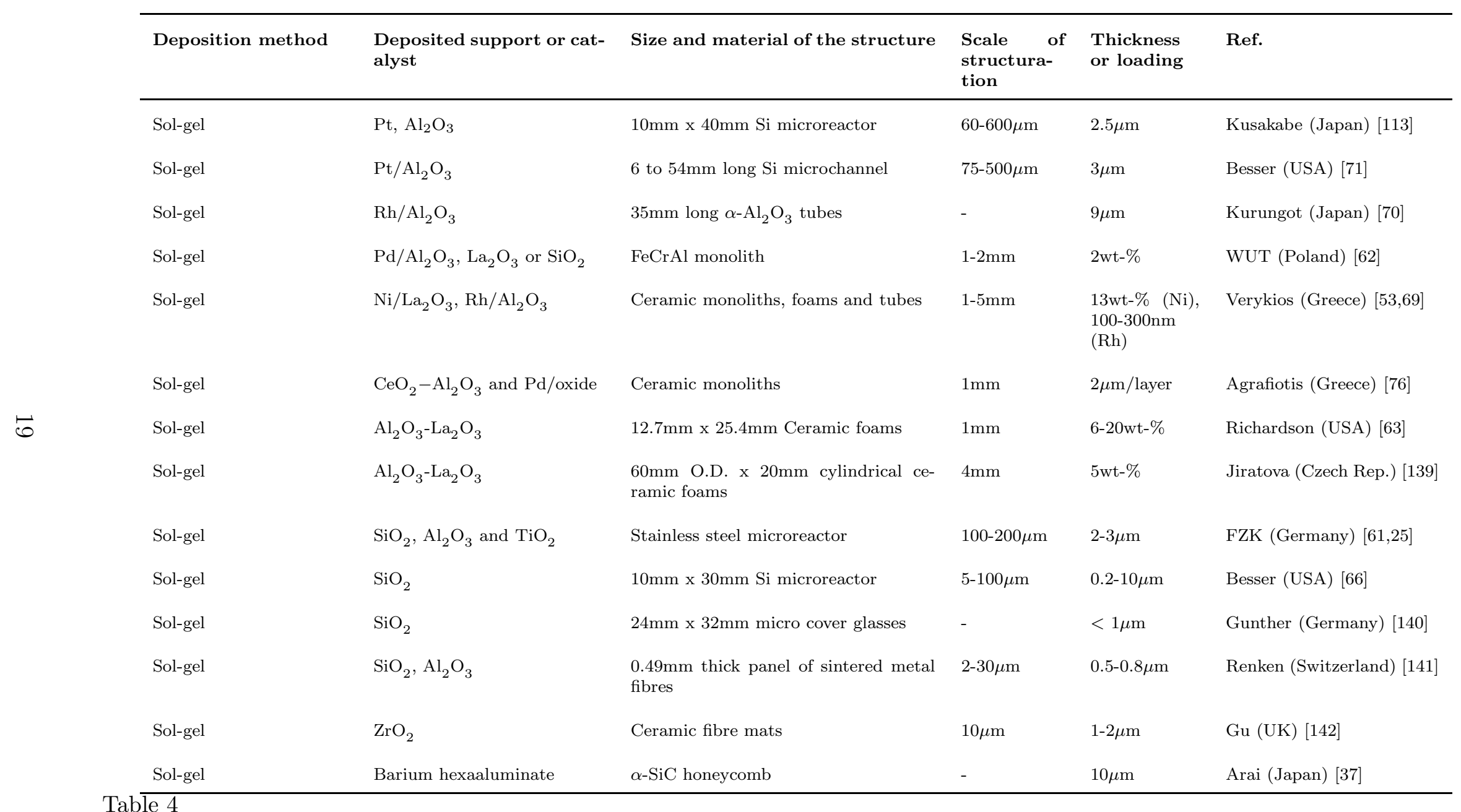

Table 4
Sol-gel method 


\begin{tabular}{|c|c|c|c|c|c|}
\hline Deposition method & $\begin{array}{l}\text { Deposited support or } \\
\text { catalyst }\end{array}$ & Size and material of the structure & $\begin{array}{l}\text { Scale of } \\
\text { structura- } \\
\text { tion }\end{array}$ & $\begin{array}{l}\text { Thickness } \\
\text { or loading }\end{array}$ & Ref. \\
\hline Electrophoretic deposition & $\mathrm{Al}_{2} \mathrm{O}_{3}$ & Stainless steel microstructured foils & $400 \mu \mathrm{m}$ & $2-4 \mu \mathrm{m}$ & FZK (Germany) [143,25] \\
\hline Electrophoretic deposition & $\mathrm{Al}_{2} \mathrm{O}_{3}$ & $\begin{array}{l}\text { Stainless steel gauze from } 50 \mu \mathrm{m} \text { O.D. } \\
\text { wires }\end{array}$ & - & $1-15 \mu \mathrm{m}$ & Vorob'eva (Russia) [94] \\
\hline Electroless plating & $\mathrm{Cu}-\mathrm{Zn}$ & $21 \mathrm{~mm} \times 120 \mathrm{~mm} \times 0.4 \mathrm{~mm} \mathrm{Al}$ plates & $1 \mathrm{~mm}$ & $50-100 \mu \mathrm{m}$ & Fukuhara (Japan) $[98,99]$ \\
\hline Electrodeposition & $\mathrm{ZrO}_{2}, \mathrm{La}_{2} \mathrm{O}_{3} / \mathrm{ZrO}_{2}$ & $\begin{array}{l}10 \mathrm{~mm} \times 10 \mathrm{~mm} \times 0.5 \mathrm{~mm} \text { stainless steel } \\
\text { plates }\end{array}$ & - & $0.5-2 \mu \mathrm{m}$ & Stoychev (Bulgaria) $[26,97]$ \\
\hline Impregnation & $\mathrm{Rh}$ & $\begin{array}{l}15 \mathrm{~mm} \times 15 \mathrm{~mm} \mathrm{Al}_{2} \mathrm{O}_{3} \text { foams and Fe- } \\
\mathrm{CrAl} \text { monolith }\end{array}$ & $100 \mu \mathrm{m}-1 \mathrm{~mm}$ & - & FZK (Germany) $[144,32]$ \\
\hline Impregnation & $\mathrm{Fe}_{2} \mathrm{O}_{3}$ & $\begin{array}{l}20 \mathrm{~mm} \times 20 \mathrm{~mm} \text { stainless steel mi- } \\
\text { crostructured foils }\end{array}$ & $70-200 \mu \mathrm{m}$ & $1-10 \mu \mathrm{m}$ & FZK (Germany) [29] \\
\hline Impregnation & $\mathrm{Ni} / \mathrm{La}_{2} \mathrm{O}_{3}$ & Cordierite monoliths & $1-5 \mathrm{~mm}$ & $9 \mathrm{wt}-\%$ & Verykios (Greece) [53] \\
\hline Precipitation & $\mathrm{Al}_{2} \mathrm{O}_{3}$ & $\begin{array}{l}\text { Woven fabrics from } 0.35 \mathrm{~mm} \text { O.D. glass } \\
\text { fibres }\end{array}$ & - & $6 \mathrm{wt}-\%$ & Renken (Switzerland) [145] \\
\hline Colloidal polymer solution & $\mathrm{Pd}$ & $450 \mathrm{~mm}$ long glass microchannel & $100 \mu \mathrm{m}$ & $18 \mu \mathrm{m}$ & Kobayashi (Japan) [146] \\
\hline CVD & $\mathrm{Al}_{2} \mathrm{O}_{3}$ & $\begin{array}{l}15 \mathrm{~mm} \times 15 \mathrm{~mm} \text { microstructured stain- } \\
\text { less steel plates }\end{array}$ & $140-200 \mu \mathrm{m}$ & $10 \mu \mathrm{m}$ & Janicke (Germany)[90] \\
\hline CVD & $\mathrm{Mo}_{2} \mathrm{C}$ & Si substrate & - & $320 \mathrm{~nm}$ & Chen (Singapore) [105] \\
\hline Plasma-CVD & $\mathrm{TiO}_{2}$ & $124 \mu \mathrm{m}$ soda-lime glass beads & - & $7-120 \mathrm{~nm}$ & Karches (Switzerland)[104] \\
\hline Langmuir-Blodgett tech. & $\mathrm{Al}_{2} \mathrm{O}_{3}$ and $\mathrm{Co}_{3} \mathrm{O}_{4}$ & $\mathrm{FeCrAl}, \mathrm{FeCrNi}$, Co leaves & $0.1-0.3 \mathrm{~mm}$ & $?$ & Lojewska (Poland) [36] \\
\hline
\end{tabular}

Table 5

Various coating methods applied to structured substrates 


\begin{tabular}{|c|c|c|c|c|c|c|}
\hline & Deposition method & $\begin{array}{l}\text { Deposited support or } \\
\text { catalyst }\end{array}$ & Size and material of the structure & $\begin{array}{l}\text { Scale of } \\
\text { structura- } \\
\text { tion }\end{array}$ & $\begin{array}{l}\text { Thickness } \\
\text { or loading }\end{array}$ & Ref. \\
\hline & Raney metal formation & Raney $\mathrm{Ni}$ or $\mathrm{Cu}$ & $\begin{array}{l}\text { Ni gauze - Ni and } \mathrm{Cu} \text { grids from } 100 \mu \mathrm{m} \\
\text { O.D. wires }\end{array}$ & - & $500 \mathrm{~nm}$ & $\begin{array}{l}\text { Renken } \quad \text { (Switzerland) } \\
{[147,148] \quad}\end{array}$ \\
\hline & Anodic oxidation & $\mathrm{Al}_{2} \mathrm{O}_{3}$ & 50mm long AlMg microreactors & $50-200 \mu \mathrm{m}$ & $3-12 \mu \mathrm{m}$ & FZK (Germany) [143,25] \\
\hline & Anodic oxidation & $\mathrm{Al}_{2} \mathrm{O}_{3}$ & $20 \mathrm{~mm}$ long microstructured $\mathrm{Al}$ plates & $280 \mu \mathrm{m}$ & $10 \mu \mathrm{m}$ & Liauw (Germany) [17] \\
\hline & Anodic oxidation & $\mathrm{Al}_{2} \mathrm{O}_{3}$ & Flat Al foil & - & $100 \mu \mathrm{m}$ & Shijie (China) [149] \\
\hline & PVD & $\mathrm{Pd}$ & $\begin{array}{l}78 \mathrm{~mm} \text { long stainless steel microchan- } \\
\text { nels }\end{array}$ & $100-300 \mu \mathrm{m}$ & $100 \mathrm{~nm}$ & IMM (Germany) [4] \\
\hline & PVD & $\mathrm{Cu}$ & $36 \mathrm{~mm} \times 36 \mathrm{~mm}$ Si microreactor & $230-1000 \mu \mathrm{m}$ & $33 \mathrm{~nm}$ & Pattekar (USA) [112] \\
\hline \multirow[t]{7}{*}{ 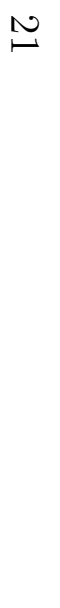 } & PVD & $\mathrm{Pt}$ & $25 \mathrm{~mm}$ x $15 \mathrm{~mm}$ Si chip & $<1 \mathrm{~mm}$ & $0.1 \mu \mathrm{m}$ & Jensen (USA) [116] \\
\hline & PVD & $\mathrm{Pt}$ & $10 \mathrm{~mm} \times 30 \mathrm{~mm}$ Si microreactor & $5-100 \mu \mathrm{m}$ & $10-40 \mathrm{~nm}$ & Besser (USA) $[109,110]$ \\
\hline & PVD & $\begin{array}{l}\text { Various oxides }\left(\mathrm{La}_{2} \mathrm{O}_{3}\right. \\
\left.\mathrm{Al}_{2} \mathrm{O}_{3} \ldots\right)\end{array}$ & 75mm O.D. Si wafer & - & $20-500 \mathrm{~nm}$ & Symyx (USA) [117] \\
\hline & PVD & $\mathrm{Pt}, \mathrm{Mo}, \mathrm{Zr}$ & $120 \mathrm{~mm}$ O.D. stainless steel titer plate & $\begin{array}{l}10 \mathrm{~mm} \\
\text { (plates) }\end{array}$ & $50-500 \mathrm{~nm}$ & IMM (Germany) [150] \\
\hline & PVD & Ti followed by $\mathrm{Pt}$ & $20 \mathrm{~mm} \times 14 \mathrm{~mm}$ Si microreactor & $50-400 \mu \mathrm{m}$ & $20 \mathrm{~nm}+20 \mathrm{~nm}$ & Cui (USA) [41] \\
\hline & FAVD & $\mathrm{NiO}-\mathrm{Al}_{2} \mathrm{O}_{3}$ & $\begin{array}{l}3.5 \mathrm{~mm} \text { O.D. } \mathrm{x} 15 \mathrm{~mm} \text { stainless steel } \\
\text { tubes }\end{array}$ & - & $100 \mu \mathrm{m}$ & Choy (UK) [120] \\
\hline & FSD & $\mathrm{Au} / \mathrm{TiO}_{2}$ & $\begin{array}{l}10 \mathrm{~mm} \times 20 \mathrm{~mm} \text { Si microreactor, } \mathrm{Ti} \text { and } \\
\mathrm{Al} \text { samples }\end{array}$ & $300 \mu \mathrm{m}$ & $50-150 \mu \mathrm{m}$ & Thybo (Denmark) [122] \\
\hline
\end{tabular}

Table 6

Physical methods used to coat structured substrates 
From these tables, it appears that sol-gel allows to produce layers around $10 \mu \mathrm{m}$ thick, whereas PVD methods produce layer thiner than $1 \mu \mathrm{m}$. The suspension methods can produce layers from 1 to hundred micrometers but is in general used to obtain thicker layers than sol-gel [44]. The method to choose thus depends on the required properties of the deposited layer. For example, to deposit a catalyst on porous substrates (foams, ceramic monoliths), two ways are possible: covering the flat surface or penetrating the porosity [151]. Giani et al. [34] found that using a sol-gel method allows to penetrate the porosity of the foam material, whereas the use of the suspension technology resulted in pore blocking (Figure 6 and 7). The same observation is made by Agrafiotis et al. [76] in the case of ceramic monolith coating. To avoid the penetration of the oxide precursor in the porosity, a hybrid method between suspension and sol-gel is prefered than sol-gel alone. Hybrid method is, in their recent publications $[152,76]$, also chosen rather than the suspension method used previously [42]. Hybrid indeed combines the advantages of the sol (precise control and tuning of the catalyst microstructure) and that of the suspension (ease of deposition). The $\mathrm{Pd}$ or $\mathrm{Rh} /(\mathrm{CeO})_{0.25}(\mathrm{CaO})_{0.02}\left(\mathrm{Al}_{2} \mathrm{O}_{3}\right)_{0.73}$ catalysts obtained by hybrid method revealed improved performances (compared to commercial catalysts) in terms of catalytic activity and resistance to thermal aging during catalytic hydrocarbon combustion. In the case of $\mathrm{TiO}_{2}$ coatings dedicated to

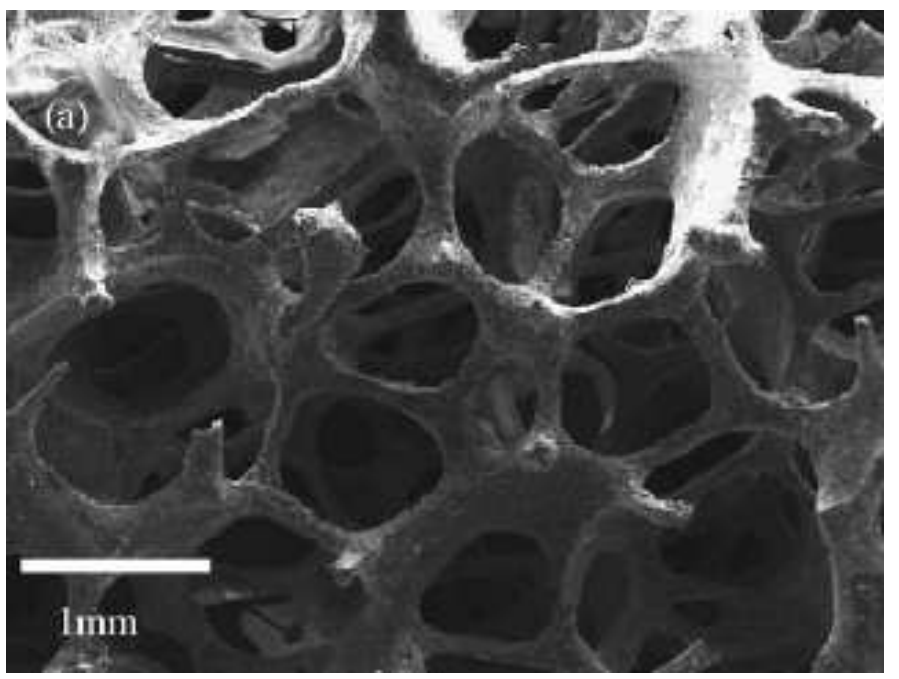

Fig. 6. FeCrAl foams coating by sol-gel method (reprinted from [34] with permission from Elsevier)

photocatalytic applications, the sol-gel method is mainly used since it alows to produce thin anatase layers, compatible with sunlight penetration (a few microns depth) [68].

From the tables, it is also obvious that various examples of microreactor technology involve the use of unsupported metallic catalysts deposited through sputtering, in accordance with observations from Yeong et al. [4]. Where greater catalytic surface area is required, anodisation of metals (typically alu- 


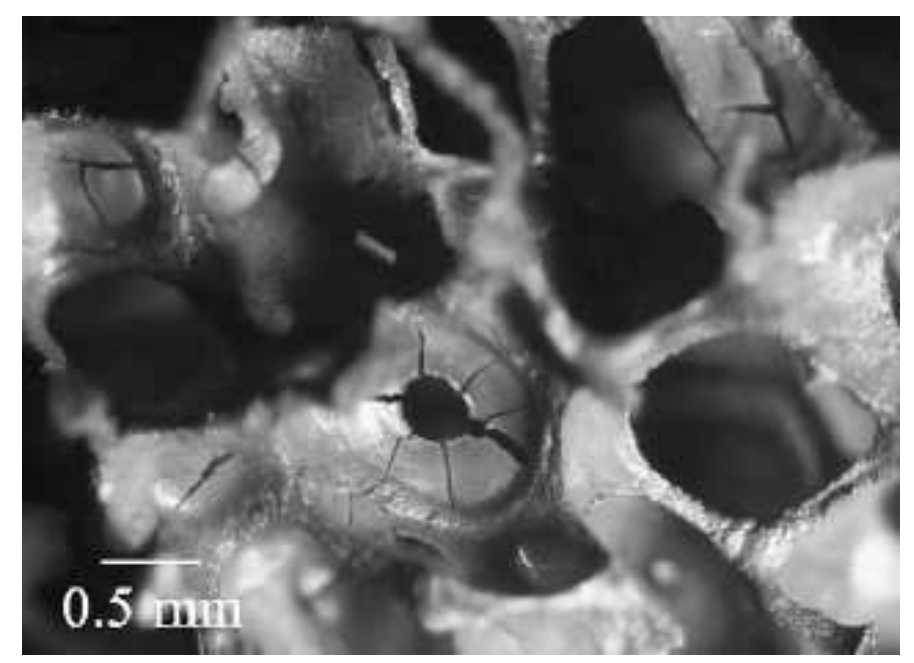

Fig. 7. FeCrAl foams coating by suspension method (reprinted from [34] with permission from Elsevier)

minium) has been used, since a variety of surface morphologies and porous layer thicknesses can be made in a controlled fashion. Supports have also been prepared using sol-gel techniques and by growing zeolites. Wunsch et al. [25] have applied three different techniques to coat channels of a micro-reactor. Anodic oxidation, sol-gel method and electrophoretic deposition all seem to give adherent $\mathrm{Al}_{2} \mathrm{O}_{3}$ layers in the channels. Micro-channels with $10 \mu \mathrm{m}$ O.D. pillars have also been coated by sol-gel method [59] (Figure 8). After impregnation of the oxide phase by a platinum precursor, the microstructured reactor was used to catalyse the oxidation of carbon monoxide as a model-reaction. Its activity was compared to a Pt-sputtered microstructured reactor. The Pt/ $\mathrm{Al}_{2} \mathrm{O}_{3}$ catalyst showed a better ignition temperature $\left(25^{\circ} \mathrm{C}\right)$ than the sputtered $\mathrm{Pt}$ $\left(100^{\circ} \mathrm{C}\right)$ [153]. PVD methods in general lead to low activity catalysts. Muller et al. also compared catalysts prepared by a wet-chemical procedure (suspension) with sputtered catalysts [150]. The ease and speed of the PVD process are very advantageous in the case of parallel screening because allow to obtain an important catalyst library in few hours and thus a rapid information on the active metals to catalyse a reaction. However, due to their low porosity, the activity of the obtained catalysts are not directly comparable to catalysts prepared by wet-chemical procedures.

The different techniques used to deposit a catalyst in a microstructure are presented in the book of Hessel et al. [154] for their application in fuel processing. PVD and CVD methods are discarded because they do not generate enough surface area to achieve sufficient reactor productivity. The sol-gel method presents some advantages; it can be automated and it can also be applied to closed microreactors. However, according to Thybo et al. [122], coating a microreactor should not involve a liquid phase handling because of non-uniform solvent removal. To overcome the problem of low activity of catalysts from CVD and PVD methods, they recommend the use of flame spray 


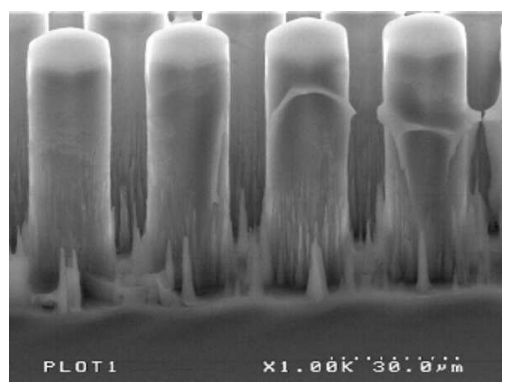

Fig. 8. Silicon microchannels with $10 \mu \mathrm{m}$ pillars coated with $\mathrm{Al}_{2} \mathrm{O}_{3}$ (reprinted from [59] with permission from Elsevier)

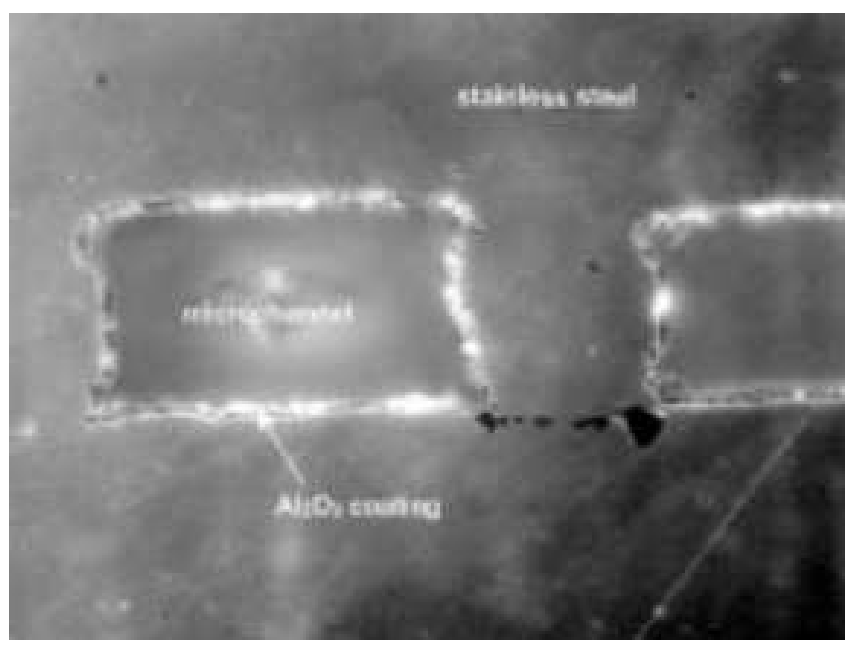

Fig. 9. $\mathrm{Al}_{2} \mathrm{O}_{3}$ deposition by sol-gel inside a microstructure (reprinted from [61] with permission from Elsevier)

synthesis which allows to obtain porous catalysts without handling a liquid precursor. In sealed microreactors, few methods can be applied. In stainless steel assembled microreactor, Haas-Santo et al. deposited an alumina coating (2-3 $\mu \mathrm{m}$ thick) prepared with a sol made of aluminum-sec-butylate and ethanol. The coatings made of this sol on single metal foils exhibited a low viscosity and the highest surface enhancement factors essential for the coating of small channels (Figure 9) [61]. The sol-gel technology was also applied by Chen et al. by infiltration in closed silicon microreactors [71]. The deposited layer was only $200 \mathrm{~nm}$.

Some examples presented in this section implicitely show an evolution in the work of several teams during the last years. To improve heat transfer at the reactor walls, ceramic monoliths have been replaced by $\mathrm{FeCrAl}$ substrates, or other highly conducting materials. As the adhesion of coatings on $\mathrm{FeCrAl}$ substrates is less easy to reach, the chemical preparations (suspension, solgel and hybrid methods) have been improved to overcome the difficulties. For example, the team of Forzatti presented in 1998 a simple preparation to obtain catalyst on ceramic tube [135] including the use of coarsely ground catalyst. 
Recently, after investigations to improve the coating method [38], the same team have published the coating of $\mathrm{FeCrAl}$ substrate, using finely crushed powder to prepare the suspension [155].

\section{Synthesis of zeolites on various structures}

The methods used to get a zeolite layer on structures differ from other oxides deposition. Methods based on a suspension of zeolite [156,157] are possible, but a direct synthesis on the structured object is most of the time applied. Applying the zeolite crystals by a dip-coating technique results in a coating consisting of randomly oriented zeolite crystal layers useful for adsorption and catalysis purposes. The support is immersed in a suspension of the zeolite crystals in a solvent containing a binder and other additives followed by evaporation of the solvent by drying and calcination. Because various zeolites are commercially available, this seems to be a relatively simple coating method, as synthesis issues concerning the zeolite itself do not need to be considered. A binder, e.g. colloidal silica, is added to the suspension for better adherence of the zeolite crystals onto the support. The obtention of BEA zeolites on ceramic monoliths and metal gauze packing is described by Beers et al. [156]. The suspension comprised BEA zeolite, a solvent (water or butyl acetate), a binder (silica sol, nitrocellulose) and a surfactant (teepol). The role of the surfactant, the solvent... in the case of suspension of zeolite is very well described in a recent review [8]. Growing the zeolites directly on the surface of the carrier is a another coating method which is detailed by Jansen et al. [158] and also well reviewed [8]. The advantage of a directly grown zeolite layer compared to the dip-coated support, is that a complete coverage of an oriented zeolite crystal layer can be achieved $[158,156]$. The preparation of directly grown MFI zeolite coatings on catalytic supports is largely reported $[159,160,108]$. The method is similar to sol-gel technology. The synthesized film can be deposited as a uniform layer at the surface, or in localized positions (e.g. in the microchannels) $[157,161,162]$. Sil-1, Al-ZSM-5 and TS-1 zeolites have thus been confined within silicon microchannels. They were synthesised from different amounts of tetrapropylammonium hydroxide, $\mathrm{SiO}_{2}, \mathrm{AlOOH}$, tetraethyl orthosilicate, tetraethyl orthotitanate and $\mathrm{NaOH}$ in water. The different results obtained in the literature are presented in Table 7. The synthesis of SAPO-5, Sil-1 and Zeolite Y on copper and steel substrates is detailed by Mintova et al. [163]. These zeolites behave differently on the different surfaces. For example, zeolite $\mathrm{Y}$ adhers to copper but not to steel. The growth of ferrierite on FeCrAl foils is also reported [164], starting from silica, alumina and piperidine, at $160^{\circ} \mathrm{C}$. To facilitate the zeolite synthesis on various substrates, Sterte et al. use the seed film method which consists of adsorbing some colloidal crystals of molecular sieve to induce its growth as a continuous film [165]. This method is also used 
by Rebrov et al. to deposit an adhering monolayer of ZSM-5 on microchannels [160] and by Chau et al. [166]. Other pretreatments than seeding have been studied. In the case of Wloch et al. [164], the FeCrAl foils were pretreated thermally to obtain alumina whiskers on the surface. Small crystals of zeolite were synthesised to favour a better contact between the metal foil and the zeolite coating. In the case of Mies et al. [108], molybdenum-containing plates were coated with ZSM-5. Different pretreatments, including chemical etching, ALD of $\mathrm{TiO}_{2}$ and $\mathrm{Al}_{2} \mathrm{O}_{3}$, UV treatment of the $\mathrm{TiO}_{2}$ layer, the use of a solution of templating agent..., were applied before zeolite synthesis. These treatments resulted in growth rate and/or nucleation rate enhancement. Jansen et al. have reviewed the supports that have been used for zeolite coatings by direct synthesis [158] with some of their possible pretreatment. Ceramics, crystal wafers, glass, steels are some examples. A review on zeolite synthesis, even not very recent, details the obtention of zeolite films on different substrates [167]. Note that many publications dealing with zeolite deposition on structures are for membrane applications.

\section{Catalysts based on carbon support deposited on various struc- tures}

\subsection{Deposition on ceramic surface}

In 2001, a review was published concerning carbon support deposited on ceramic monoliths [168]. Only a summary of the three methods used will be found here, details and references being found in the cited review. The first method (melting method) consists in heating the ceramic structure together with the coal tar pitch in an inert atmosphere. Upon heating, the pitch melts and penetrates the pores of the ceramic structure. Then, a carbonisation is performed at $800-1000^{\circ} \mathrm{C}$. A more frequently used method (polymerisation method) consists of a liquid polymer or polymer solution which is used as carbon precursor and impregnates cordierite monolithic structures. The cordierite structure is dip-coated into the liquid polymer, which can be either a resole (phenolformaldehyde resin produced with an alkaline catalyst) or a furan-type resin [e.g., poly(furfuryl alcohol)] [169]. The polymer coating is converted into carbon by heating the composite in an inert atmosphere up to $550-1000^{\circ} \mathrm{C}$. In the last method (CVD method), an alumina washcoated monolith is heated in an oven to $600-700^{\circ}$ Cin nitrogen. The gas flow is switched to a cyclohexenecontaining gas flow, so that cyclohexene is decomposed and carbon is deposited onto the alumina coating of the monolithic structure. This method can thus be applied to all structures described in the first paragraph and containing a layer of alumina. It derives from a method applied by Vissers et al. [170] to alumina (or boehmite) particles. Cyclohexene or ethene have been used. Apart 
from this three methods, Garcia-Bordeje et al. [171] have also used a suspension of commercial carbon support in furan. This resulted in an increased mesoporosity compared to the method with furan-type resin alone. Once the carbon surface is obtained, it needs to be activated. The role of carbon activation is also well described in the review of Vergunst [168]. Under an oxidising treatment (air, ozone, nitric acid... ) it allows the modification of the textural properties of the carbon by the creation of pores. Some indications on how to develop the pore structure of carbon can be found in [172-175]. A further functionalisation of the surface is required to generate anchoring sites for the catalyst according to well-known methods for the preparation of carbon supported catalysts [176]. This can be perfomed by immersing the carbon-coated object in $\mathrm{NaOCl}$ (up to $15 \mathrm{wt}-\%$ active chlorine) [177], in concentrated $\mathrm{HNO}_{3}$ or in hydrogen peroxide for durations varying from one author to another. Carbon nanofibres (CNF) have also been applied on ceramic monoliths $[178,179]$. The carbon nanofibres are grown on $\mathrm{Ni} / \mathrm{Al}_{2} \mathrm{O}_{3}$-washcoated monolith by a gas containing 50\% methane. Table 7 summarizes carbon coating results.

\subsection{Deposition on metallic surfaces}

At least one method described in the previous paragraph seems to adapt well to non-porous objects: without significant modification of the polymer preparation, Schimpf et al. [180] applied the furan-type resin to AlMg structured wafers (Figure 10). Surprisingly, although carbon is the most employed catalyst support in chemical industry, no other publication deals with direct carbon coating on other substrates than ceramics. An alternative concerns carbon nanotubes growth. Carbon nanotubes arrays have been grown on FeCrAlY foams, but after several intermediate layers: i) thermal oxidation of FeCrAl, ii) $\mathrm{Al}_{2} \mathrm{O}_{3}$ deposited by CVD, iii) $\mathrm{Fe} / \mathrm{SiO}_{2}$ deposited by CVD (serving as the seeding layer for carbon nanotube growing) [181]. The growth of carbon nanotubes was then carried out by catalytic decomposition of ethylene at $700{ }^{\circ} \mathrm{C}$. The authors further deposited a bimetallic Co-Re/ $\mathrm{Al}_{2} \mathrm{O}_{3}$ by sol-gel method. Jarrah et al. obtained some carbon nanofibres on $\mathrm{Ni}$ foams also using ethylene as carbon precursor [182]. They found that an oxidative pretreatment of the nickel was beneficial to the CNF (carbon nanofibres) growth. 


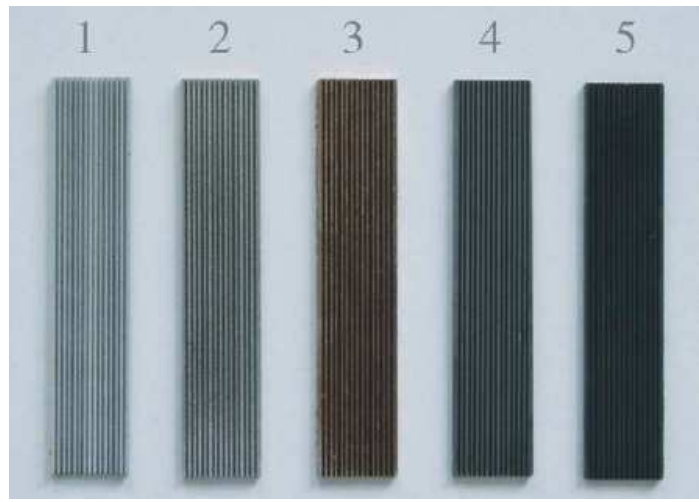

Fig. 10. Different steps during preparation of carbon coatings in submillimetric channels (reprinted from [180] with permission from Elsevier) 


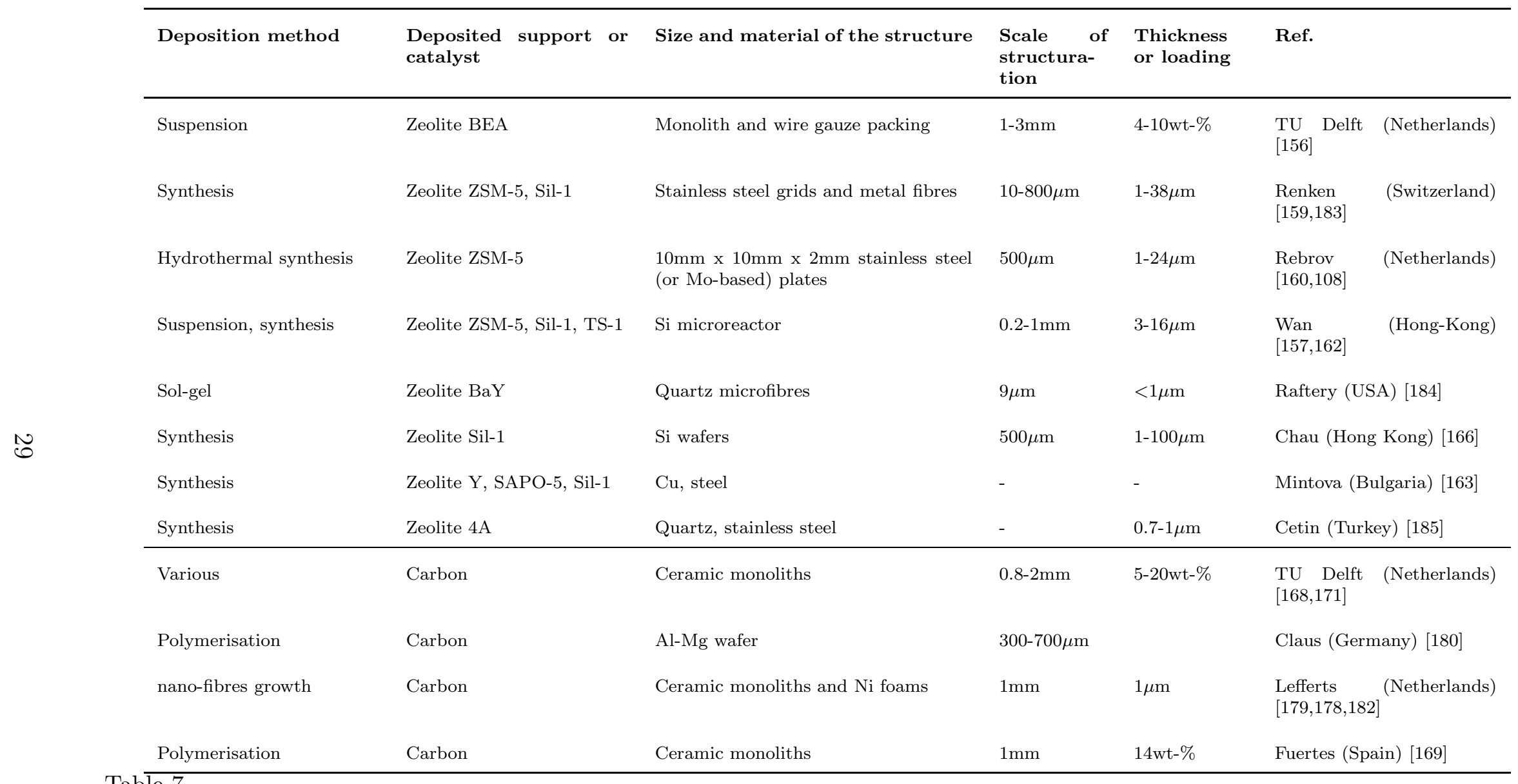

Table 7
Results from the literature concerning zeolite and carbon deposition on structured substrates 


\section{Conclusion}

A list of the different methods published to deposit a catalyst on structured surfaces has been reviewed. The main data concern metal-on-oxide catalysts for which many methods exist. Some concern a physical treatment of the surface to coat (anodisation, plating, PVD...), other involve a more or less complex chemical preparation (suspension and sol-gel). The properties of the deposited layer vary to a large extent, e.g. the thickness, from nanometer (PVD) to near millimeter scale (suspension). The textural properties of the oxide supports can in certain cases reach that of traditional catalysts (suspension, sol-gel, powder plasma spraying methods). "Physical" methods in general lead to more adherent layers, but to less active catalysts. Some results are given concerning zeolite deposition. The most used method is a direct synthesis on the surface. Concerning carbon deposition, very few methods are published, especially on metallic structures.

\section{References}

[1] X. Xiaoding, J. A. Moulijn, Structured catalysts and reactors, CRC Taylor \& Francis, 2005, Ch. Transformation of a structured carrier into a structured catalyst, pp. $751-777$.

[2] G. Kolb, R. Zapf, V. Hessel, H. Lowe, Propane steam reforming in microchannels: results from catalyst screening and optimisation, Appl. Catal. A 277 (2004) 155-166.

[3] P. Pfeifer, K. Schubert, G. Emig, Preparation of copper catalyst washcoats for methanol steam reforming in microchannels based on nanoparticles, Appl. Catal. A. 286 (2005) 175-185.

[4] K. K. Yeong, A. Gavriilidis, R. Zapf, V. Hessel, Catalyst preparation and deactivation issues for nitrobenzene hydrogenation in a microstructured falling film reactor, Catal. Today 81 (2003) 641-651.

[5] R. Abdallah, V. Meille, J. Shaw, D. Wenn, C. de Bellefon, Gas-liquid and gasliquid-solid catalysis in a mesh microreactor, Chem. Commun. (2004) 372-373.

[6] M. W. Losey, M. A. Schmidt, K. F. Jensen, Microfabricated multiphase packed-bed reactors: Characterization of mass transfer and reactions, Ind. Eng. Chem. Res. 40 (2001) 2555-2562.

[7] T. A. Nijhuis, A. E. W. Beers, T. Vergunst, I. Hoek, F. Kapteijn, J. A. Moulijn, Preparation of monolithic catalysts, Catal. Rev. Sci. Eng. 43 (2001) 345-380.

[8] P. Avila, M. Montes, E. E. Miro, Monolithic reactors for environmental applications: A review on preparation technologies, Chem. Eng. J. 109 (2005) $11-36$. 
[9] V. Hessel, P. Angeli, A. Gavriilidis, H. Lowe, Gas-liquid and gas-liquid-solid microstructured reactors: Contacting principles and applications, Ind. Eng. Chem. Res. 44 (2005) $9750-9769$.

[10] S. Zhao, J. Zhang, D. Weng, X. Wu, A method to form well-adhered gamma$\mathrm{Al}_{2} \mathrm{O}_{3}$ layers on FeCrAl metallic supports, Surf. Coat. Technol. 167 (2003) $97-105$.

[11] X. Wu, D. Weng, L. Xu, H. Li, Structure and performance of $\gamma$-alumina washcoat deposited by plasma spraying, Surf. Coat. Technol. 145 (2001) 226232 .

[12] X. Wu, D. Weng, S. Zhao, W. Chen, Influence of an aluminized intermediate layer on the adhesion of a $\gamma-\mathrm{Al}_{2} \mathrm{O}_{3}$ washcoat on FeCrAl, Surf. Coat. Technol. 190 (2005) 434-439.

[13] C. Baratto, G. Sberveglieri, E. Comini, G. Faglia, G. Benussi, V. L. Ferrara, L. Quercia, G. D. Francia, V. Guidi, D. Vincenzi, D. Boscarino, V. Rigato, Gold-catalysed porous silicon for NOx sensing, Sens. Actuators, B. 68 (2000) $74-80$.

[14] M. C. Kim, D. K. Song, H. S. Shin, S. H. Baeg, G. S. Kim, J. H. Boo, J. G. Han, S. H. Yang, Surface modification for hydrophilic property of stainless steel treated by atmospheric-pressure plasma jet, Surf. Coat. Technol. 171 (2003) $312-316$.

[15] G. Wiessmeier, D. Hnicke, Heterogeneously catalyzed gas-phase hydrogenation of cis,trans,trans-1,5,9-cyclododecatriene on palladium catalysts having regular pore systems, Ind. Eng. Chem. Res. 35 (1996) 4412 - 4416.

[16] R. Fodisch, D. Honicke, Y. Xu, B. Platzer, Liquid phase hydrogenation of pnitrotoluene in microchannel reactors, in: M. E. Baselt (Ed.), Microreaction technology. IMRET 5 : Proceedings, Springer, 2001, pp. 470-478.

[17] S. Walter, E. Joannet, M. Schiel, I. Boullet, R. Philipps, M. A. Liauw, Microchannel reactor for the partial oxidation of isoprene, in: M. E. Baselt (Ed.), Microreaction technology. IMRET 5 : Proceedings, Springer, 2001, pp. 387-396.

[18] E. V. Rebrov, M. H. J. M. de Croon, J. C. Schouten, Development of a cooled microreactor for platinum catalyzed ammonia oxidation, in: M. E. Baselt (Ed.), Microreaction technology. IMRET 5 : Proceedings, Springer, 2001, pp. 49-59.

[19] S.-J. Lee, A. Gavriilidis, Au catalysts supported on anodised aluminium for low-temperature CO-oxidation, Catal. Commun. 3 (2002) 425-428.

[20] Z. Ni, E. G. Seebauer, R. I. Masel, Effects of microreactor geometry on performance: Differences between posted reactors and channel reactors, Ind. Eng. Chem. Res. 44 (2005) 4267-4271.

[21] J. Ganley, K. Riechmann, E. Seebauer, R. Masel, Porous anodic alumina optimized as a catalyst support for microreactors, J. Catal. 227 (2004) 2632 . 
[22] L. Guillou, V. L. Courtois, D. Vanhove, Preparation d'un support catalytique poreux par oxydation anodique d'une plaque en alliage d'aluminium, Materiaux \& Techniques 93 (2005) 1-8.

[23] T. Giornelli, A. Lofberg, E. Bordes-Richard, Grafting of $\mathrm{VOx} / \mathrm{TiO}_{2}$ catalyst on anodized aluminum plates for structured catalytic reactors, Thin solid films 479 (2005) 64-72.

[24] I. Ismagilov, R. Ekatpure, L. Tsykoza, E. Matus, E. Rebrov, M. de Croon, M. Kerzhentsev, J. Schouten, Optimization of anodic oxidation and $\mathrm{Cu}-\mathrm{Cr}$ oxide catalyst preparation on structured aluminum plates processed by electro discharge machining, Catal. Today 105 (2005) 516-528.

[25] R. Wunsch, M. Fichtner, O. Gorke, K. Haas-Santo, K. Schubert, Process of applying $\mathrm{Al}_{2} \mathrm{O}_{3}$ coatings in microchannels of completely manufactured microstructured reactors, Chem. Eng. Technol. 25 (2002) 700-703.

[26] P. Stefanov, D. Stoychev, I. Valov, A. K. Georgieva, T. Tarinova, Electrochemical deposition of thin zirconia films on stainless steel $316 \mathrm{~L}$., Mater. Chem. Phys. 65 (2000) 222-225.

[27] V. Lysenko, J. Vitiello, B. Remaki, D. Barbier, Gas permeability of porous silicon nanostructures, Phys. Rev. E 70 (2004) 017301.

[28] P. Reuse, A. Renken, K. Haas-Santo, O. Goerke, K. Schubert, Hydrogen production for fuel cell application in an autothermal micro-channel reactor, Chem. Eng. J. 101 (2004) 133-141.

[29] O. Goerke, P. Pfeifer, K. Schubert, Water gas shift reaction and selective oxidation of CO in microreactors, Appl. Catal. A 263 (2004) 11-18.

[30] X. Yu, S.-T. Tu, Z. Wang, Y. Qi, Development of a microchannel reactor concerning steam reforming of methanol, Chem. Eng. J. 116 (2006) 123-132.

[31] A. R. Tadd, B. D. Gould, J. W. Schwank, Packed bed versus microreactor performance in autothermal reforming of isooctane, Catal. Today 110 (2005) $68-75$.

[32] I. Aartun, T. Gjervan, H. Venvik, O. Goerke, P. Pfeifer, M. Fathi, A. Holmen, K. Schubert, Catalytic conversion of propane to hydrogen in microstructured reactors, Chem. Eng. J. 101 (2004) 93-99.

[33] J. Camra, E. Bielanska, A. Bernasik, K. Kowalski, M. Zimowska, A. Bialas, M. Najbar, Role of $\mathrm{Al}$ segregation and high affinity to oxygen in formation of adhesive alumina layers on FeCr alloy support, Catal. Today 105 (2005) 629-633.

[34] L. Giani, C. Cristiani, G. Groppi, E. Tronconi, Washcoating method for $\mathrm{Pd}$ /gamma- $\mathrm{Al}_{2} \mathrm{O}_{3}$ deposition on metallic foams, Appl. Catal. B 62 (2006) 121131.

[35] Y.-S. Seo, S.-P. Yu, S.-J. Cho, K.-S. Song, The catalytic heat exchanger using catalytic fin tubes, Chem. Eng. Sci. 48 (2003) 43-53. 
[36] J. Lojewska, A. Kolodziej, P. Dynarowicz-Latka, A. Weselucha-Birczynska, Engineering and chemical aspects of the preparation of microstructured cobalt catalyst for VOC combustion, Catal. Today 101 (2005) 81-91.

[37] H. Inoue, K. Sekizawa, K. Eguchi, H. Arai, Thermal stability of hexaaluminate film coated on $\mathrm{SiC}$ substrate for high-temperature catalytic application, J. Am. Ceram. Soc. 80 (1997) 584-588.

[38] M. Valentini, G. Groppi, C. Cristiani, M. Levi, E. Tronconi, P. Forzatti, The deposition of $\mathrm{Al}_{2} \mathrm{O}_{3}$ layers on ceramic and metallic supports for the preparation of structured catalysts, Catal. Today 69 (2001) 307-314.

[39] J. P. Reymond, Structured supports for noble catalytic metals: stainless steel fabrics and foils, and carbon fabrics, Catal. Today 69 (2001) 343-349.

[40] A. Suknev, A. van Veen, A. Toktarev, E. Sadovskaya, B. Bal'zhinimaev, C. Mirodatos, NO decomposition over a new type of low metal content fiberglass catalysts studied by the TAP technique, Catal. Commun. 5 (2004) 691-695.

[41] T. Cui, J. Fang, F. Jones, A. Reppond, Fabrication of microreactors for dehydrogenation of cyclohexane to benzene, Sens. Actuators, B 71 (2000) 228231.

[42] C. Agrafiotis, A. Tsetsekou, A. Ekonomakou, The effect of particle size on the adhesion properties of oxide washcoats on cordierite honeycombs, J. Mater. Sci. Lett. 18 (1999) 1421-1424.

[43] J. R. Gonzalez-Velasco, M. A. Gutierrez-Ortiz, J. L. Marc, J. A. Botas, M. P. Gonzalez-Marcos, G. Blanchard, $\mathrm{Pt} / \mathrm{Ce}_{0.68} \mathrm{Zr}_{0.32} \mathrm{O}_{2}$ washcoated monoliths for automotive emission control, Ind. Eng. Chem. Res. 42 (2003) 311-317.

[44] R. Zapf, C. Becker-Willinger, K. Berresheim, H. Bolz, H. Gnaser, V. Hessel, G. Kolb, P. Loeb, A.-K. Pannwitt, A. Ziogas, Detailed characterization of various porous alumina-based catalyst coatings within microchannels and their testing for methanol steam reforming, Chem. Eng. Res. Des., TransIChemE 81 (2003) 721-729.

[45] Y. Men, H. Gnaser, R. Zapf, V. Hessel, C. Ziegler, G. Kolb, Steam reforming of methanol over $\mathrm{Cu} / \mathrm{CeO}_{2} / \gamma-\mathrm{Al}_{2} \mathrm{O}_{3}$ catalysts in a microchannel reactor, Appl. Catal. A 277 (2004) 83-90.

[46] C. Agrafiotis, A. Tsetsekou, The effect of processing parameters on the properties of $\gamma$-alumina washcoats deposited on ceramic honeycombs, J. Mater. Sci. 35 (2000) 951-960.

[47] Z. Jiang, K.-S. Chung, G.-R. Kim, J.-S. Chung, Mass transfer characteristics of wire-mesh honeycomb reactors, Chem. Eng. Sci. 58 (2003) 1103-1111.

[48] K.-S. Chung, Z. Jiang, B.-S. Gill, J.-S. Chung, Oxidative decomposition of o-dichlorobenzene over $\mathrm{V}_{2} \mathrm{O}_{5} / \mathrm{TiO}_{2}$ catalyst washcoated onto wire-mesh honeycombs, Appl. Catal. A 237 (2002) 81-89. 
[49] P. Pfeifer, K. Schubert, M. A. Liauw, G. Emig, PdZn catalysts prepared by washcoating microstructured reactors, Appl. Catal. A 270 (2004) 165-175.

[50] P. Pfeifer, O. Gorke, K. Schubert, Washcoats and electrophoresis with coated and uncoated nanoparticles on microstructured metal foils and microstructured reactors, in: Proceedings of IMRET 6, AIChE pub. 164, 2002, pp. 281-287.

[51] Y. Choi, K. Tajima, W. Shin, N. Izu, I. Matsubara, N. Murayama, Combustor of ceramic Pt/alumina catalyst and its application for micro-thermoelectric hydrogen sensor, Appl. Catal. A. 287 (2005) 19-24.

[52] P. Reuse, P. Tribolet, L. Kiwi-Minsker, A. Renken, Catalyst coating in microreactors for methanol steam reforming, in: M. E. Baselt (Ed.), Microreaction technology. IMRET 5 : Proceedings, Springer, 2001, pp. 322331.

[53] D. K. Liguras, K.Goundani, X. E. Verykios, Production of hydrogen for fuel cells by catalytic partial oxidation of ethanol over structured Ni catalysts, J. Power Sources 130 (2004) 30-37.

[54] H. Ding, D. Weng, X. Wu, Effect of rare earth on the thermostability and the surface area of auto-catalyst washcoats, J. Alloys Compd. 311 (2000) 26-29.

[55] A. V. Boix, E. E. Miro, R. Lombardo, E. A.; Mariscal, J. L. G. Fierro, Binder effect upon the catalytic behavior of PtCoZSM5 washcoated on cordierite monoliths, Appl. Catal. A 276 (2004) 197-205.

[56] R. Kikuchi, S. Maeda, K. Sasaki, S. Wennerstrm, Y. Ozawa, K. Eguchi, Catalytic activity of oxide-supported $\mathrm{Pd}$ catalysts on a honeycomb for lowtemperature methane oxidation, Appl. Catal. A 239 (2003) 169-179.

[57] J.-M. Bae, S. Ahmed, R. Kumar, E. Doss, Microchannel development for autothermal reforming of hydrocarbon fuels, J. Power Sources 139 (2005) 191195.

[58] X. Xiaoding, H. Vonk, A. Cybulski, J. A. Moulijn, Alumina washcoating and metal deposition of ceramic monoliths, Stud. Surf. Sci. Catal. (1995) 10691078.

[59] V. Meille, S. Pallier, G. V. Santa Cruz Bustamante, M. Roumanie, J. Reymond, Deposition of $\gamma-\mathrm{Al}_{2} \mathrm{O}_{3}$ layers on structured supports for the design of new catalytic reactors, Appl. Catal. A 286 (2005) 232-238.

[60] S. Schimpf, M. Lucas, C. Mohr, U. Rodemerck, A. Bruckner, J. Radnik, H. Hofmeister, P. Claus, Supported gold nanoparticles : in-depth catalyst characterization and application in hydrogenation and oxidation reactions, Catal. Today 72 (2002) 63-78.

[61] K. Haas-Santo, M. Fichtner, K. Schubert, Preparation of microstructure compatible porous supports by sol-gel synthesis for catalyst coatings, Appl. Catal. A: 220 (2001) 79-92. 
[62] B. Kucharczyk, W. Tylus, L. Kepinski, Pd-based monolithic catalysts on metal supports for catalytic combustion of methane, Appl. Catal. B 49 (2004) 27-37.

[63] J. T. Richardson, M. Garrait, J. K. Hung, Carbon dioxide reforming with Rh and Pt-Re catalysts dispersed on ceramic foam supports, Appl. Catal. A 255 (2003) 69-82.

[64] A. Y. Tonkovich, J. L. Zilka, M. J. LaMont, Y. Wang, R. S. Wegeng, Microchannel reactors for fuel processing applications. I. water gas shift reactor, Chem. Eng. Sci. 54 (1999) 2947-2951.

[65] A. Ayral, A. el Mansouri, M. P. Vieira, C. Pilon, Porosity of sol-gel derived silica coatings on glass substrates, J. Mater. Sci. Lett. 17 (1998) 883-885.

[66] S. Zhao, R. Besser, Selective deposition of supported platinum catalyst for hydrogenation in a micromachined reactor, in: Proceedings of IMRET 6, AIChE pub. 164, 2002, pp. 289-296.

[67] A. Danion, J. Disdier, C. Guillard, O. Paisse, N. Jaffrezic-Renault, Photocatalytic degradation of imidazolinone fungicide in $\mathrm{TiO}_{2}$-coated optical fiber reactor, Appl. Catal. B 62 (2006) 274-281.

[68] M. Yates, E. Garcia, Controlled porosity and surface area titania gels as novel photocatalytic washcoats, in: Studies in Surface Science and Catalysis, Vol. 144, Elsevier, 2002, pp. 737-744.

[69] T. Ioannides, X. E. Verykios, Catalytic partial oxidation of methane in a novel heat-integrated wall reactor, Catal. Lett. 47 (1997) 183-188.

[70] S. Kurungot, T. Yamaguchi, S.-I. Nakao, $\mathrm{Rh} / \mathrm{Al}_{2} \mathrm{O}_{3}$ catalytic layer integrated with sol-gel synthesized microporous silica membrane for compact membrane reactor applications, Catal. Lett. 86 (2003) $273-278$.

[71] H. Chen, L. Bednarova, R. Besser, W. Lee, Surface-selective infiltration of thin-film catalyst into microchannel reactors, Appl. Catal. A. 286 (2005) 186195.

[72] N. Huesing, B. Launay, G. Kickelbick, S. Gross, L. Armelao, G. Bottaro, M. Feth, H. Bertagnolli, G. Kothleitner, Transition metal oxide-doped mesostructured silica films, Appl. Catal. A 254 (2003) 297-310.

[73] F. Fajula, A. Galarneau, F. Renzo, Advanced porous materials: New developments and emerging trends, Microporous Mesoporous Mater. 82 (2005) $227-239$.

[74] M. F. M. Zwinkels, S. G. Jaras, P. G. Menon, Preparation of combustion catalysts by washcoating alumina whiskers-covered metal monoliths using a sol-gel method, in: Preparation of Catalysts VI, Vol. 91 of Studies in Surface Science and Catalysis, Elsevier, 1995, pp. 85-94.

[75] A. Rouge, B. Spoetzl, K. Gebauer, R. Schenk, A. Renken, Microchannel reactors for fast periodic operation: the catalytic dehydration of isopropanol, Chem. Eng. Sci. 56 (2001) 1419-1427. 
[76] C. Agrafiotis, A. Tsetsekou, C. J. Stournaras, A. Julbe, L. Dalmazio, C. Guizard, Evaluation of sol-gel methods for the synthesis of doped-ceria environmental catalysis systems. part I: preparation of coatings, J. Eur. Ceram. Soc. 22 (2002) 15-25.

[77] G. Groppi, C. Cristiani, M. Valentini, E. Tronconi, Development of novel structured catalytic reactors for highly exothermic reactions, in: 12th international congress on catalysis, Vol. 130 of Studies in Surface Science and catalysis, Elsevier, 2000, pp. 2747-2752.

[78] E. Tronconi, G. Groppi, A study on the thermal behavior of structured platetype catalysts with metallic supports for gas/solid exothermic reactions, Chem. Eng. Sci. 55 (2000) 6021-6036.

[79] J. Bravo, A. Karim, T. Conant, G. P. Lopez, A. Datye, Wall coating of a $\mathrm{CuO} / \mathrm{ZnO} / \mathrm{Al}_{2} \mathrm{O}_{3}$ methanol steam reforming catalyst for micro-channel reformers, Chem. Eng. J. 101 (2004) 113-121.

[80] G.-G. Park, D. J. Seo, S.-H. Park, Y.-G. Yoon, C.-S. Kim, W.-L. Yoon, Development of microchannel methanol steam reformer, Chem. Eng. J. 101 (2004) 87-92.

[81] G. Germani, P. Alphonse, M. Courty, Y. Schuurman, C. Mirodatos, Platinum/ceria/alumina catalysts on microstructures for carbon monoxide conversion, Catal. Today 110 (2005) 114-120.

[82] M. S. Lim, M. R. Kim, J. Noh, S. I. Woo, A plate-type reactor coated with zirconia-sol and catalyst mixture for methanol steam-reforming, J. Power Sources 140 (2005) 66-71.

[83] J. Y. Won, H. K. Jun, M. K. Jeon, S. I. Woo, Performance of microchannel reactor combined with combustor for methanol steam reforming, Catal. Today 111 (2006) 158-163.

[84] A. Karim, J. Bravo, D. Gorm, T. Conant, A. Datye, Comparison of wall-coated and packed-bed reactors for steam reforming of methanol, Catal. Today 110 (2005) 86-91.

[85] S. Walter, S. Malmberg, B. Schmidt, M. Liauw, Mass transfer limitations in microchannel reactors, Catal. Today 110 (2005) 15-25.

[86] M. Schuessler, M. Portscher, U. Limbeck, Monolithic integrated fuel processor for the conversion of liquid methanol, Catal. Today 79-80 (2003) 511-520.

[87] R. W. Sidwell, H. Zhu, B. A. Kibler, R. J. Kee, D. T. Wickham, Experimental investigation of the activity and thermal stability of hexaaluminate catalysts for lean methane-air combustion, Appl. Catal. A 255 (2003) 279-288.

[88] O. Younes-Metzler, J. Svagin, S. Jensen, C. H. Christensen, O. Hansen, U. Quaade, Microfabricated high-temperature reactor for catalytic partial oxidation of methane, Appl. Catal. A 284 (2005) 5-10. 
[89] Y.-Y. Huang, K.-S. Chou, Studies on the spin coating process of silica films, Ceram. Int. 29 (2003) 485-493.

[90] M. T. Janicke, H. Kestenbaum, U. Hagendorf, F. Schuth, M. Fichtner, K. Schubert, The controlled oxidation of hydrogen from an explosive mixture of gases using a microstructured reactor/heat exchanger and $\mathrm{Pt} / \mathrm{Al}_{2} \mathrm{O}_{3}$ catalyst, J. Catal. 191 (2000) 282-293.

[91] C. H. Chen, M. H. J. Emond, E. M. Kelder, B. Meester, J. Schoonman, Electrostatic sol-spray deposition of nanostructured ceramic thin films, J. Aerosol Sci. 30 (1999) 959-967.

[92] M. Nomura, B. Meester, J. Schoonman, F. Kapteijn, J. A. Moulijn, Preparation of thin porous titania films on stainless steel substrates for heat exchange reactors, Sep. Purif. Technol. 32 (2003) 387-395.

[93] W. E. Windes, J. Zimmerman, I. E. Reimanis, Electrophoretic deposition applied to thick metal-ceramic coatings, Surf. Coat. Technol. 157 (2002) 267273.

[94] M. P. Vorob'eva, A. A. Greish, A. V. Ivanov, L. M. Kustov, Preparation of catalyst carriers on the basis of alumina supported on metallic gauzes, Appl. Catal. A 199 (2000) 257-261.

[95] K. S. Yang, Z. Jiang, J. S. Chung, Electrophoretically Al-coated wire mesh and its application for catalytic oxidation of 1,2-dichlorobenzene, Surf. Coat. Technol. 168 (2003) 103-110.

[96] H. Lowe, W. Ehrfeld, State-of-the-art in microreaction technology: concepts, manufacturing and applications, Electrochimica acta 44 (1999) 3679-3689.

[97] G. Tyuliev, D. Panayotov, I. Avramova, D. Stoichev, T. Marinova, Thin film coating of $\mathrm{Cu}$-Co oxide catalyst on lanthana/zirconia films electrodeposited on stainless steel, Mater. Sci. Eng. C. 23 (2003) 117-121.

[98] C. Fukuhara, H. Ohkura, Y. Kamata, Y. Murakami, A. Igarashi, Catalytic properties of plate-type copper-based catalysts, for steam reforming of methanol, on an aluminum plate prepared by electroless plating, Appl. Catal. A 273 (2004) 125-132.

[99] C. Fukuhara, Y. Kamata, A. Igarashi, Catalytic performance of microtubetype copper-based catalyst for methanol steam reforming, prepared on the inner wall of an aluminum tube by electroless plating, Appl. Catal. A 296 (2005) 100-107.

[100] H.-G. Ahn, J.-D. Lee, Performance of double wash-coated monolith catalyst in selective catalytic reduction of NOx with propene, in: Studies in Surface Science and Catalysis, Vol. 146, Elsevier, 2003, pp. 701-704.

[101] Y. Matatov-Meytal, V. Barelko, I. Yuranov, M. Sheintuch, Cloth catalysts in water denitrification I. Pd on glass fibers, Appl. Catal. B 27 (2000) 127-135. 
[102] M. J. Ledoux, C. Pham-Huu, Silicon carbide, a novel catalyst support for heterogeneous catalysis, Cattech 5 (2001) 226-246.

[103] D. P. Norton, Synthesis and properties of epitaxial electronic oxide thin-film materials, Mater. Sci. Eng., R 43 (2004) 139-247.

[104] M. Karches, M. Morstein, P. Rudolf von Rohr, R. Pozzo, J. Giombi, M. Baltanas, Plasma-CVD-coated glass beads as photocatalyst for water decontamination, Catal. Today 72 (2002) 267-279.

[105] H. Y. Chen, L. Chen, Y. Lu, Q. Hong, H. C. Chua, S. B. Tang, J. Lin, Synthesis, characterization and application of nano-structured $\mathrm{Mo}_{2} \mathrm{C}$ thin films, Catal. Today 96 (2004) 161-164.

[106] T. Aaltonen, M. Ritala, T. Sajavaara, J. Keinonen, M. Leskela, Atomic layer deposition of platinum thin films, Appl. Catal. A 15 (2003) 1924-1928.

[107] J. Keranen, C. Guimon, E. Iiskola, A. Auroux, L. Niinisto, Atomic layer deposition and surface characterization of highly dispersed titania/silicasupported vanadia catalysts, Catal. Today 78 (2003) 149-157.

[108] M. Mies, J. van den Bosch, E. Rebrov, J. Jansen, M. de Croon, J. Schouten, Hydrothermal synthesis and characterization of ZSM-5 coatings ona molybdenum support and scale-up for application in micro reactors, Catal. Today 110 (2005) 38-46.

[109] H. Surangalikar, X. Ouyang, R. S. Besser, Experimental study of hydrocarbon hydrogenation and dehydrogenation reactions in silicon microfabricated reactors of two different geometries, Chem. Eng. J. 93 (2003) 217-224.

[110] R. S. Besser, X. Ouyang, H. Surangalikar, Hydrocarbon hydrogenation and dehydrogenation reactions in microfabricated catalytic reactors, Chem. Eng. Sci. 58 (2003) 19-26.

[111] M. Roumanie, V. Meille, C. Pijolat, G. Tournier, C. de Bellefon, P. Pouteau, C. Delattre, Design and fabrication of a structured catalytic reactor at micrometer scale : example of methylcyclohexane dehydrogenation, Catal. Today 110 (2005) 164-170.

[112] A. V. Pattekar, M. V. Kothare, S. V. Karnik, M. K. Hatalis, A microreactor for in-situ hydrogen production by catalytic methanol reforming, in: M. E. Baselt (Ed.), Microreaction technology. IMRET 5 : Proceedings, Springer, 2001, pp. $332-342$.

[113] K. Kusakabe, D. Miyagawa, Y. Gu, H. Maeda, S. Morooka, Development of a self-heating catalytic microreactor, in: M. E. Baselt (Ed.), Microreaction technology. IMRET 5 : Proceedings, Springer, 2001, pp. 70-77.

[114] R. Bruning, P. Scholz, I. Morgenthal, O. Andersen, J. Scholz, G. Nocke, B. Ondruschka, Innovative catalysts for oxidative dehydrogenation in the gas phase - metallic short fibers and coated glass fabrics, Chem. Eng. Technol. 28 (2005) 1056-1062. 
[115] H. Kestenbaum, A. L. de Oliveira, W. Schmidt, F. Schuth, W. Ehrfeld, K. Gebauer, H. Lowe, T. Richter, D. Lebiedz, I. Untiedt, H. Zuchner, Silvercatalyzed oxidation of ethylene to ethylene oxide in a microreaction system, Ind. Eng. Chem. Res. 41 (2002) 710-719.

[116] R. Srinivasan, I. Hsing, P. Berger, K. Jensen, S. Firebaugh, M. Schmidt, M. Harold, J. Lerou, J. Ryley, Micromachined reactors for catalytic partial oxidation reactions, AIChE J. 43 (1997) 3059-3069.

[117] E. Danielson, J. H. Golden, E. W. McFarland, C. M. Reaves, W. H. Weinberg, $\mathrm{X}$. D. Wu, A combinatorial approach to the discovery and optimization of luminescent materials, Nature 389 (1997) 944-948.

[118] H. Shinguu, M. Bhuiyan, T. Ikegami, K. Ebihara, Preparation of $\mathrm{TiO}_{2} / \mathrm{WO}_{3}$ multilayer thin film by PLD method and its catalytic response to visible light, Thin Solid Films 506-507 (2006) 111-114.

[119] M. Klimczak-Chmielowska, R. Chmielowski, A. Kopia, J. Kusinski, S. Villain, C. Leroux, J.-R. Gavarri, Multiphase $\mathrm{CuO}_{z}-\mathrm{CeO}_{2-\delta}$ thin films by pulsed laser deposition technique: experimental texture evolutions and kinetics modeling, Thin Solid Films 458 (2004) 98-107.

[120] K. Choy, H.-K. Seh, Fabrication of Ni- $\mathrm{Al}_{2} \mathrm{O}_{3}$-based reforming catalyst using flame-assisted vapour deposition, Mater. Sci. Eng., A 281 (2000) 253-258.

[121] R. L. Jones, Surface and coatings effects in catalytic combustion in internal combustion engines, Surf. Coat. Technol. 94-95 (1997) 118-122.

[122] S. Thybo, S. Jensen, J. Johansen, T. Johannessen, O. Hansen, U. J. Quaade, Flame spray deposition of porous catalysts on surfaces and in microsystems, J. Catal. 223 (2004) 271-277.

[123] Z. Ismagilov, O. Podyacheva, O. Solonenko, V. Pushkarev, V. Kuz'min, V. Ushakov, N. Rudina, Application of plasma spraying in the preparation of metal-supported catalysts, Catal. Today 51 (1999) 411-417.

[124] Z. R. Ismagilov, V. V. Pushkarev, O. Y. Podyacheva, N. A. Koryabkina, $\mathrm{H}$. Veringa, A catalytic heat-exchanging tubular reactor for combining of high temperature exothermic and endothermic reactions, Chem. Eng. J. 82 (2001) $355-360$.

[125] L. L. Pranevicius, P. Valatkevicius, V. Valincius, C. Montassier, Catalytic behavior of plasma-sprayed $\mathrm{Al}-\mathrm{Al}_{2} \mathrm{O}_{3}$ coatings doped with metal oxides, Surf. Coat. Technol. 125 (2000) 392-395.

[126] L. Pranevicius, L. L. Pranevicius, P. Valatkevicius, V. Valincius, Plasma spray deposition of $\mathrm{Al}-\mathrm{Al}_{2} \mathrm{O}_{3}$ coatings doped with metal oxides: catalytic applications, Surf. Coat. Technol. 123 (2000) 122-128.

[127] P. Chin, X. Sun, G. W. Roberts, J. J. Spivey, Preferential oxidation of carbon monoxide with iron-promoted platinum catalysts supported on metal foams, Appl. Catal. A 302 (2006) 22-31. 
[128] A. Sirijaruphan, J. G. Goodwin, R. W. Rice, D. Wei, K. R. Butcher, G. W. Roberts, J. J. Spivey, Metal foam supported Pt catalysts for the selective oxidation of CO in hydrogen, Appl. Catal. A 281 (2005) 1-9.

[129] I. Cerri, M. Pavese, G. Saracco, V. Specchia, Premixed metal fibre burners based on a Pd catalyst, Catal. Today 83 (2003) 19-31.

[130] H. Redlingshofer, O. Krocher, W. Boch, K. Huthmacher, G. Emig, Catalytic wall reactor as a tool for isothermal investigations in the heterogeneously catalyzed oxidation of propene to acrolein, Ind. Eng. Chem. Res. 41 (2002) $1445-1453$.

[131] B. Amon, H. Redlingshofer, E. Klemm, E. Dieterich, G. Emig, Kinetic investigations of the deactivation by coking of a noble metal catalyst in the catalytic hydrogenation of nitrobenzene using a catalytic wall reactor, Chem. Eng. Process. 38 (1999) 395-404.

[132] J. G. McCarty, Kinetics of PdO combustion catalysis, Catal. Today 26 (1995) 283-293.

[133] Y. Wang, Y. Chin, R. Rozmiarek, B. Johnson, Y. Gao, J. Watson, A. Tonkovich, D. V. Wiel, Highly active and stable $\mathrm{Rh} / \mathrm{MgO}$ single bond $\mathrm{Al}_{2} \mathrm{O}_{3}$ catalysts for methane steam reforming, Catal. Today 98 (2004) 575-581.

[134] C. V. Rice, D. Raftery, Photocatalytic oxidation of trichloroethylene using $\mathrm{TiO}_{2}$ coated optical microfibers, Chem. Commun. (1999) 895-896.

[135] A. Beretta, P. Baiardi, D. Prina, P. Forzatti, Development of a catalytic reactor with annular configuration, in: Preparation of Catalysts VII, Studies in Surface Science and Catalysis, Elsevier, 1998, pp. 541-549.

[136] P. Jiang, G. Lu, Y. Guo, Y. Guo, S. Zhang, X. Wang, Preparation and properties of a $\gamma-\mathrm{Al}_{2} \mathrm{O}_{3}$ washcoat deposited on a ceramic honeycomb, Surf. Coat. Technol. 190 (2005) 314-320.

[137] S. Belochapkine, J. Shaw, D. Wenn, J. R. Ross, The synthesis by depositionprecipitation of porous gamma-alumina catalyst supports on glass substrates compatible with microreactor geometries, Catal. Today 110 (2005) 53-57.

[138] P. Cini, S. R. Blaha, M. P. Harold, K. Venkataraman, Preparation and characterization of modified tubular ceramic membranes for use as catalyst supports, J. Memb. Sci. 55 (1991) 199-225.

[139] K. Jiratova, L. Moravkova, J. Malecha, B. Koutsky, Ceramic foam-supported perovskites as catalysts for combustion of methane, Collect. Czech. Chem. Commun. 62 (1997) 875-883.

[140] L. Gunther, W. Peukert, Control of coating properties by tailored particle interactions: relation between suspension rheology and film structure, Colloids Surf. A Physicochem. Eng. Aspects 225 (2003) 49-61.

[141] I. Yuranov, L. Kiwi-Minsker, A. Renken, Structured combustion catalysts based on sintered metal fibre filters, Appl. Catal. B 43 (2003) 217-227. 
[142] X. Gu, P. A. Trusty, E. G. Butler, C. B. Ponton, Deposition of zirconia sols on woven fibre preforms using a dip-coating technique, J. Eur. Ceram. Soc. 20 (2000) 675-684.

[143] K. Haas-Santo, O. Gorke, P. Pfeifer, K. Schubert, Catalyst coatings for microstructure reactors, Chimia 56 (2002) 605-610.

[144] I. Aartun, B. Silberova, H. Venvik, P. Pfeifer, O. Goerke, K. Schubert, A. Holmen, Hydrogen production from propane in Rh-impregnated metallic microchannel reactors and alumina foams, Catal. Today 105 (2005) 469-478.

[145] V. Holler, I. Yuranov, L. Kiwi-Minsker, A. Renken, Structured multiphase reactors based on fibrous catalysts: nitrite hydrogenation as a case study, Catal. Today 69 (2001) 175-181.

[146] J. Kobayashi, Y. Mori, K. Okamoto, R. Akiyama, M. Ueno, T. Kitamori, S. Kobayashi, A microfluidic device for conducting gas-liquid-solid hydrogenation reactions, Science 304 (2004) 1305-1308.

[147] B. Monnerat, L. Kiwi-Minsker, A. Renken, Hydrogen production by catalytic cracking of methane over nickel gauze under periodic reactor operation, Chem. Eng. Sci. 56 (2001) 633-639.

[148] I. Yuranov, N. Dunand, L. Kiwi-Minsker, A. Renken, Metal grids with high-porous surface as structured catalysts: preparation, characterization and activity in propane total oxidation, Appl. Catal. B: 36 (2002) 183-191.

[149] L. Shijie, Y. Weiyong, F. Dingye, K. Hideo, Kinetics of catalytic combustion in air over Pt/ $\mathrm{Al}_{2} \mathrm{O}_{3} / \mathrm{Al}$ catalyst, React. Kinet. Catal. Lett. 85 (2005) 205-213.

[150] A. Muller, K. Drese, H. Gnaser, M. Hampe, V. Hessel, H. Lowe, S. Schmitt, R. Zapf, Fast preparation and testing methods using a microstructured modular reactor for parallel gas phase catalyst screening, Catal. Today 81 (2003) 377-391.

[151] M. V. Twigg, J. T. Richardson, Preparation and properties of ceramic foam catalyst supports, in: Preparation of catalysts VI, Vol. 91 of Studies in Surface Science and Catalysis, elsevier, 1995, pp. 345-360.

[152] C. Agrafiotis, A. Tsetsekou, C. J. Stournaras, A. Julbe, L. Dalmazio, C. Guizard, G. Boretto, M. Debenedetti, F. Parussa, Evaluation of sol-gel methods for the synthesis of doped-ceria environmental catalysis systems: Part II. catalytic activity and resistance to thermal aging, Appl. Cata. B 34 (2001) $149-159$.

[153] M. Roumanie, C. Pijolat, V. Meille, C. D. Bellefon, P. Pouteau, C. Delattre, Deposition of Pt-catalyst in a micro-channel of a silicon reactor: Application to gas micro-TAS working at high temperature, Sens. Actuators B in press.

[154] V. Hessel, H. Lowe, A. Muller, G. Kolb, Chemical micro process engineering, Wiley-VCH, 2005. 
[155] C. Cristiani, M. Valentini, M. Merazzi, S. Neglia, P. Forzatti, Effect of ageing time on chemical and rheological evolution in gamma- $\mathrm{Al}_{2} \mathrm{O}_{3}$ slurries for dipcoating, Catal. Today 105 (2005) 492-498.

[156] A. E. W. Beers, T. A. Nijhuis, N. Aalders, F. Kapteijn, J. A. Moulijn, BEA coating of structured supports - performance in acylation, Appl. Catal. A: 243 (2003) 237-250.

[157] Y. S. S. Wan, J. L. H. Chau, A. Gavriilidis, K. L. Yeung, Design and fabrication of zeolite-based microreactors and membrane microseparators, Microporous Mesoporous Mater. 42 (2001) 157-175.

[158] J. Jansen, J. Koegler, H. van Bekkum, H. Calis, C. van den Bleek, F. Kapteijn, J. Moulijn, E. Geus, N. van der Puil, Zeolitic coatings and their potential use in catalysis, Microporous Mesoporous Mater. 21 (1998) 213-226.

[159] B. Louis, L. Kiwi-Minsker, P. Reuse, A. Renken, ZSM-5 coatings on stainless steel grids in one-step benzene hydroxylation to phenol by $\mathrm{N}_{2} \mathrm{O}$ : reaction kinetics study, Ind. Eng. Chem. Res. 40 (2001) 1454-1459.

[160] E. V. Rebrov, G. B. F. Seijger, H. P. A. Calis, M. H. J. M. de Croon, C. M. van den Bleek, J. C. Schouten, The preparation of highly ordered single layer ZSM-5 coating on prefabricated stainless steel microchannels, Appl. Catal. A 206 (2001) 125-143.

[161] Y. S. S. Wan, J. L. H. Chau, A. Gavriilidis, K. L. Yeung, Design and fabrication of zeolite-containing microstructures, in: M. E. Baselt (Ed.), Microreaction technology. IMRET 5 : Proceedings, Springer, 2001, pp. 94-102.

[162] Y. S. S. Wan, A. Gavriilidis, K. L. Yeung, 1-pentene epoxidation in titanium silicate-1 microchannel reactor - experiments and modelling, Chem. Eng. Res. Des., Trans IChemE 81 (2003) 753-759.

[163] S. Mintova, V. Valtchev, L. Konstantinov, Adhesivity of molecular sieve films on metal substrates, Zeolites 17 (1995) 462-465.

[164] E. Wloch, A. Lukaszczyk, Z. Zurek, B. Sulikowski, Synthesis of ferrierite coatings on the FeCrAl substrate, Catal. Today 114 (2006) 231-236.

[165] J. Sterte, J. Hedlund, D. Creaser, O. Ohrman, W. Zheng, M. Lassinantti, Q. Li, F. Jareman, Application of the seed-film method for the preparation of structured molecular sieve catalysts, Catal. Today 69 (2001) 323-329.

[166] J. L. H. Chau, Y. S. S. Wan, A. Gavriilidis, K. L. Yeung, Incorporating zeolites in microchemical systems, Chem. Eng. J. 88 (2002) 187-200.

[167] T. Bein, Synthesis and applications of molecular sieve layers and membranes, Chem. Mater. 8 (1996) 1636-1653.

[168] T. Vergunst, M. J. G. Linders, F. Kapteijn, J. A. Moulijn, Carbon based monolithic structures, Catal. Rev. - Sci. Eng. 43 (2001) 291-314. 
[169] T. Valdes-Solis, G. Marban, A. B. Fuertes, Preparation of microporous carbonceramic cellular monoliths, Microporous Mesoporous Mater. 43 (2001) 113126.

[170] J. P. R. Vissers, F. P. M. Mercx, S. M. A. M. Bouwens, V. H. J. de Beer, R. Prins, Carbon-covered alumina as a support for sulfide catalysts, J. Catal. 114 (1988) 291-302.

[171] E. Garcia-Bordeje, F. Kapteijn, J. Moulijn, Preparation and characterisation aspects of carbon-coated monoliths, Catal. Today 69 (2001) 357-363.

[172] K. P. Gadkaree, M. Jaroniec, Pore structure development in activated carbon honeycombs, Carbon 38 (2000) 983-993.

[173] Y. Otake, R. G. jenkins, Characterization of oxygen-containing surface complexes created on a microporous carbon by air and nitric acid treatment, Carbon 31 (1993) 109-121.

[174] E. Garcia-Bordeje, M. Lazaro, R. Moliner, P. Alvarez, V. Gomez-Serrano, J. Fierro, Vanadium supported on carbon coated honeycomb monoliths for the selective catalytic reduction of $\mathrm{NO}$ at low temperatures: Influence of the oxidation pre-treatment, Carbon 44 (2006) 407-417.

[175] K. F. M. J. Crezee E, Barendregt A, Carbon coated monolithic catalysts in the selective oxidation of cyclohexanone, Catal. Today 69 (2001) 283-290.

[176] D. Richard, P. Gallezot, Preparation of highly dispersed, carbon supported, platinum catalysts, in: Preparation of catalysts IV, Stud. Surf. Sci. Catal., 1987, pp. 71-81.

[177] T. Vergunst, F. Kapteijn, J. A. Moulijn, Carbon coating of ceramic monolithic substrates, Preparation of catalysts, VII (1998) 175-183.

[178] N. A. Jarrah, J. G. van Ommen, L. Lefferts, Growing a carbon nano-fiber layer on a monolith support; effect of nickel loading and growth conditions, J. Mater. Chem. 14 (2004) 1590-1597.

[179] N. Jarrah, J. G. van Ommen, L. Lefferts, Development of monolith with a carbon-nanofiber-washcoat as a structured catalyst support in liquid phase, Catal. Today 79-80 (2003) 29-33.

[180] S. Schimpf, M. Bron, P. Claus, Carbon-coated microstructured reactors for heterogeneously catalyzed gas phase reactions: influence of coating procedure on catalytic activity and selectivity, Chem. Eng. J. 101 (2004) 11-16.

[181] Y. huei Chin, J. Hu, C. Cao, Y. Gao, Y. Wang, Preparation of a novel structured catalyst based on aligned carbon nanotube arrays for a microchannel fischer-tropsch synthesis reactor, Catal. Today 110 (2005) 4752 .

[182] N. A. Jarrah, J. G. van Ommen, L. Lefferts, Mechanistic aspects of the formation of carbon-nanofibers on the surface of $\mathrm{Ni}$ foam: A new microstructured catalyst support, J. Catal. 239 (2006) 460-469. 
[183] I. Yuranov, A. Renken, L. Kiwi-Minsker, Zeolite/sintered metal fibers composites as effective structured catalysts, Appl. Catal. A 281 (2005) 5560 .

[184] A. R. Pradhan, M. A. Macnaughtan, D. Raftery, Zeolite-coated optical microfibers for intrazeolite photocatalysis studied by in situ solid-state NMR, J. Am. Chem. Soc. 122 (2000) 404-405.

[185] T. Cetin, M. Tatlier, A. Erdem-Imageenatalar, U. Demirler, M. Urgen, Lower temperatures for the preparation of thinner zeolite A coatings, Microporous Mesoporous Mater. 47 (2001) 1-14. 